San Jose State University

SJSU ScholarWorks

Master's Theses

Master's Theses and Graduate Research

Spring 2012

\title{
Prey and Plastic Ingestion of Pacific Northern Fulmars (Fulmarus glacialis) Collected in Monterey Bay, California
}

Erica Lynn Donnelly-Greenan

San Jose State University

Follow this and additional works at: https://scholarworks.sjsu.edu/etd_theses

\section{Recommended Citation}

Donnelly-Greenan, Erica Lynn, "Prey and Plastic Ingestion of Pacific Northern Fulmars (Fulmarus glacialis) Collected in Monterey Bay, California" (2012). Master's Theses. 4129.

DOI: https://doi.org/10.31979/etd.7sga-vxdm

https://scholarworks.sjsu.edu/etd_theses/4129

This Thesis is brought to you for free and open access by the Master's Theses and Graduate Research at SJSU ScholarWorks. It has been accepted for inclusion in Master's Theses by an authorized administrator of SJSU ScholarWorks. For more information, please contact scholarworks@sjsu.edu. 


\title{
PREY AND PLASTIC INGESTION OF PACIFIC NORTHERN FULMARS (FULMARUS GLACIALIS) COLLECTED IN MONTEREY BAY, CALIFORNIA
}

\author{
A Thesis \\ Presented to \\ The Faculty of Moss Landing Marine Laboratories \\ and the Department of Biology \\ California State University, San Jose
}

In Partial Fulfillment

of the Requirements for the Degree

Master of Science

by

Erica L. Donnelly

May 2012 
(C) 2012

Erica L. Donnelly

ALL RIGHTS RESERVED 
The Designated Thesis Committee Approves the Thesis Titled

PREY AND PLASTIC INGESTION OF PACIFIC NORTHERN FULMARS (FULMARUS GLACIALIS) COLLECTED IN MONTEREY BAY, CALIFORNIA

by

Erica L. Donnelly

APPROVED FOR MOSS LANDING MARINE LABORATORIES AND THE

DEPARTMENT OF BIOLOGY

SAN JOSÉ STATE UNIVERSITY

May 2012

Dr. James T. Harvey Moss Landing Marine Laboratories

Dr. William Walker National Marine Mammal Laboratory

Dr. Scott Shaffer Department of Biological Sciences 


\title{
ABSTRACT \\ PREY AND PLASTIC INGESTION OF PACIFIC NORTHERN FULMARS (FULMARUS GLACIALIS) COLLECTED IN MONTEREY BAY, CALIFORNIA
}

\author{
By Erica L. Donnelly
}

Marine plastic pollution affects seabirds that mistake it for prey or incidentally ingest it with prey. Northern Fulmars (Fulmarus glacialis) and seabirds that feed at the water's surface ingest the most plastic. This can cause health issues, including satiety that possibly leads to inefficient foraging. The objectives of this study were to examine fulmar body condition, identify cephalopod diet and ingested plastic, predict foraging areas, and determine if prey number and size was correlated with ingested plastics in Pacific Northern Fulmars (Fulmarus glacialis rodgersii). Cephalopod prey were identified, measured, and enumerated; plastic and marine debris were categorized, enumerated, and weighed from beach-cast Northern Fulmars wintering in Monterey Bay, California, during 2003 and 2007. Fulmars ate mostly Gonatid squids (Gonatus pyros, G. onyx, and G. californiensis) in similar size classes for both years. There was a significant negative correlation between pectoral muscle index and average size of cephalopod beaks per stomach, a significant increase in multiple plastic categories between years, and no significant correlation between the number and mass of plastic compared with the number and size of prey for either year. Although there was no correlation between plastic and prey, other issues with ingested plastics (contaminant accumulation, endocrine disruption, and micro plastics) should be further examined as plastic pollution increases in the world's oceans. 


\section{ACKNOWLEDGEMENTS}

This work was partially funded by Oikonos and supported by the Dr. Earl and Ethel Myers Oceanographic and Marine Biology Trust and the Graduate Equity Scholarship. A special "thanks” to my major advisor, James T. Harvey, and my thesis committee members, William Walker (NMML) and Scott Shaffer (SJSU). Thank you to Jan van Franeker (IMARES) who inspired this study and was always informative, approachable, and quick to answer emails on the other side of the world. A special “thank you” to Hannah Nevins (CDFG) and Michelle Hester (Oikonos) for the years of mentoring, collaboration, encouragement, and the opportunity to work on this project. This study would have not been successful without the help and support of the MLML Vertebrate Ecology Lab (particularly Corinne Gibble and Colleen Young), Simon Brown (MLML), BeachCOMBERS volunteers, Kim Starbuck (who originally sorted the 2003 samples), Dr. Herbert Lee (UCSC), and my husband Dr. Kevin Greenan (UCSC alumni). 


\section{TABLE OF CONTENTS}

Acknowledgment and Dedication..............................................v

List of Figures.............................................................

List of Tables.......................................................................

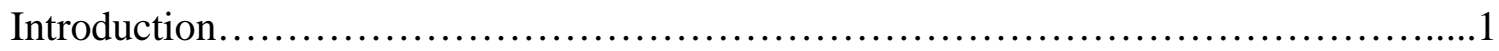

Methods..........................................................................

Results...................................................................14

Discussion................................................................... 31

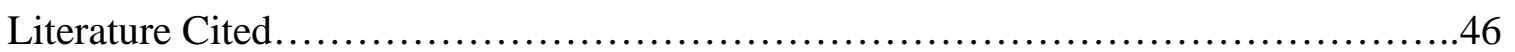




\section{LIST OF FIGURES}

Figure 1: Graphical analysis of feeding strategy diagram reprinted from Costello et al. 1996 indicating interpretation of feeding strategy, niche width contribution, and prey importance, and characteristic niche curves

Figure 2: Distribution of estimated dorsal mantle lengths ( $\mathrm{mm}$ ) for Gonatus pyros, $G$. californiensis, and G. onyx in 2003 and 2007

Figure 3: Frequency distribution of estimated masses (g) for Gonatus pyros, G. californiensis, and G. onyx in 2003 and 2007

Figure 4: Modified Costello plots (adapted from Amudsen et al. 1996) of identified cephalopods from the Northern Fulmars for 2003 (top) and 2007 (bottom)

Figure 5: Canonical Correlation Analysis of the plastic variables and cephalopod beak variables

Figure 6: Distributions of the three dominant cephalopod species (a) Gonatus californiensis, (b) G. onyx, and (c) G. pyros in the 2003 and 2007 Northern Fulmar stomach samples 


\section{LIST OF TABLES}

Table 1: Number of demographic measurements and body condition indices recorded for the Northern Fulmar samples collected in 2003 and 2007

Table 2: Occurrence (number of beaks) and zone distribution of identified cephalopods (family and species) from the stomachs of Northern Fulmar in 2003 and 2007

Table 3: MANOVA comparisons of prey variables (number and average lower rostral lengths (mm) of cephalopod beaks per stomach) versus the demographics and body condition indices of Northern Fulmar samples between years and within years (2003 and 2007)

Table 4: Mean and Standard Errors (SE) of number and masses (g) of marine debris, all plastic, industrial plastic, and user plastic categories for the 2003 and 2007 samples

Table 5: Multivariate Analysis of Variance (MANOVA) comparisons of demographics and body condition indices versus the number and masses (g) of all the plastic categories for the Northern Fulmar samples for 2003 and 2007

Table 6: Analysis of Variance (ANOVA) results of the ln transformed plastic categories where the number and the masses (g) for the 2003 and 2007 fulmars of the following categories were compared: marine debris, all plastic, industrial plastic, and user plastic

Table 7: Canonical Correlation Analysis correlations between number and mass (g) of the plastic (industrial and user categories) compared with the number and average Lower Rostral Length (mm) of cephalopod beaks per stomach for 2003, 2007, and both years pooled

Table 8: Previously identified cephalopod beaks: family, species, number, and location from Northern Fulmar stomachs in earlier decades 


\section{Introduction}

Plastic waste occurs throughout the world's oceans as surface, bottom, or coastline debris, and often becomes aggregated in convergence zones (Shaw \& Mapes 1979). Winds, currents, and geographic inputs aggregate plastic at convergence zones (Shaw \& Mapes 1979, Dameron 2007, Pichel et al. 2007), which are important foraging areas for pelagic seabirds, marine mammals, and turtles, thus increasing their chances of ingesting plastic (Polovina et al. 2001, Seki et al. 2002, Pichel et al. 2007).

Seabirds that feed at the water's surface (e.g. Procellariiformes; Albatrosses, Petrels, and Fulmars) ingest the most plastic (Nevins et al. 2005). Procellariiforms that forage at the water's surface are opportunistic, and presumably mistake floating plastic for prey items. Bottle caps, cigarette lighters, balloons, toys, and other fragments have been recovered from Procellariiforms with increasing frequency (van Franeker \& Meijboom 2002, Nevins et al. 2005, Mallory et al. 2006). Furthermore, prey can be attached to floating debris and ingested by seabirds (i.e., flying fish deposit their egg masses on floating debris; Sileo et al. 1989).

Documented cases of plastic ingestion by Northern Fulmars are rapidly increasing in regions of the North Atlantic (Moser \& Lee 1992, van Franeker \& Meijboom 2002) and North Pacific (Robards et al. 1995, Nevins et al. 2005, Mallory et al. 2006). Greater than $80 \%$ of fulmars sampled from the Atlantic and Pacific from 1975 to 1990 contained plastics (van Franeker 1985, Moser \& Lee 1992, Robards et al. 1995). Recently, 71-88\% of Pacific fulmars (Robards et al. 1997, Nevins et al. 2005) and 95-99\% of North Atlantic 
fulmars (Fulmarus glacialis glacialis) contained some form of plastics (van Franeker \& Meijboom 2002).

Programs monitoring marine litter have indicated increased ingestion of plastics in Northern Fulmars (van Franeker et al. 2005). The programs keep detailed accounts of plastic debris in Northern Fulmars, and enable regular monitoring of abundance of litter in foraging areas (van Franeker \& Meijboom 2002). In addition to plastic, stomachs also contain indigestible hard parts of prey items (e.g. squid beaks, fish otoliths, and invertebrate exoskeletons) used to determine prey size and species. Fulmars in the Pacific eat primarily cephalopods and fish (Baltz \& Morejohn 1977, Harrington-Tweit 1979, Hunt et al. 1981, Sanger 1983, Hills \& Fiscus 1988, Gould et al. 1997), whereas fulmars in the Artic and Atlantic consume more fishes (Cherl et al. 2001). Van Franeker and Meijboom (2002) examined the stomach contents of 329 fulmars washed ashore between 1982 and 2000 in the North Atlantic. They reported 78\% of fulmars had prey remains (all types totaled), and 96\% contained plastic. These findings indicate that incidence of plastic in Northern Fulmars is greater than prey, and may result in health complications in fulmars.

Direct and indirect health effects are associated with plastic ingestion. Effects include reduced hunger (satiety), internal blockage, contaminant accumulation, and negative correlations between bird fat indices or mass in relation to ingested plastic (Pettit et al. 1981, Day et al. 1985, Zonfrillo 1985, Frey et al. 1987, Pierce et al. 2004, Mallory et al. 2006). Inability or difficulty regurgitating hard material (plastics and prey 
parts) can interfere directly with the bird's digestion causing gastrointestinal blockage (Day 1980, Pierce et al. 2004) or indirectly by reducing feeding stimulus and activity (Sturkie 1965 as cited in Azzarello \& Van Vleet 1987). Unlike most seabird species, Northern Fulmars have a constriction between the gizzard and proventriculus making regurgitation improbable (Furness 1985, Azzarello \& Van Vleet 1987). As a result, plastics and prey hard parts (e.g., cephalopod beaks) are retained for an unknown amount of time.

In addition to the constriction, the gizzard is relatively small and susceptible to distension in individuals carrying large plastic loads. Distension of the gizzard in fulmars may lead to decreased stomach contractions (Day 1980). Contractions signal the absence of food, therefore, hunger and foraging effort would decrease as plastic loads increase (Connors \& Smith 1982, Day et al. 1985, Ryan 1988). In addition to satiation effects, accumulated plastics may reduce maximum food load (volume of food that can be ingested in one foraging bout; van Franeker \& Meijboom 2002). Presently, evidence for satiation effects are difficult to attribute solely to plastic ingestion, however, decreased sense of hunger, decreased urge to forage, and a decrease in ingested volume of food will negatively affect the condition of the bird, eventually resulting in mortality (Pierce et al. 2004).

Plastic often is not the direct cause of mortality, but it may reduce the physical fitness of the seabird. Decreased physical fitness can affect reproduction and decrease chances of survival (van Franeker \& Meijboom 2002). In the 1980s, researchers reported 
weak negative correlations between seabird body condition and mass, number, and volume of plastics (Day 1980, Furness 1985, Ryan 1987). Others indicated, however, significant, positive correlations when age and season were assessed as covariates (Connors \& Smith 1982). Positive correlations were possible if plastic was concentrated in the same locations as prey and better foragers found the optimal foraging areas (Spear et al. 1995). Positive correlations also could be attributed to location of feeding (Young et al. 2009). Spear et al. (1995) was the first to report significant negative correlations between the number of plastic particles and body mass. These results and earlier negative correlations could result from one or a combination of the following: (1) direct damage or blockage of the digestive track or impairment of digestive efficiency; (2) indirect damage that caused reduced mass from toxins that leach from ingested plastic; and (3) the birds were already in poor body condition and ate more plastic due to reduced foraging efficiency (Spear et al. 1995). Although the third explanation is a possibility, it is inconsistent with the previous finding that birds in better body condition contained more internal plastic (Spear et al. 1995). Additionally, the prey may have ingested the plastic before the birds foraged on them (i.e. secondary ingestion; Eriksson \& Burton 2003).

Of those previous researchers who reported negative correlations between bird mass and plastic load (Spear et al 1995, Sivert \& Sileo 1993, Auman et al. 1997), none concurrently reported the prey remains in the seabirds. Previously, researchers have examined diet or plastic ingestion in Northern Fulmars, but have not examined both 
variables together (Baltz \& Morejohn 1977, Sanger 1983, Hills \& Fiscus 1988, van Franeker \& Meijboom 2002, Nevins et al. 2005). Frequency of occurrence and general types of prey ingested has been determined from Fulmar stomach contents, but prey identified to species, particularly cephalopods, has rarely occurred. Twelve cephalopod families were found in the stomach contents of Fulmars in the 1970s, 1980s, and early 1990s, but more recent identification of cephalopods from Northern Fulmar stomachs has not occurred. Furthermore, if greater plastic loads lead to satiety or reduced foraging efficiency in Northern Fulmars, a change in prey items (i.e. different size classes, species, frequency of occurrence, etc.) may occur. In this study, I examine the possible correlation between Northern Fulmar plastic loads and the occurrence and size of prey species because plastic loads may be influencing the types of prey ingested or vice versa.

Because fulmars foraging in the North Pacific contain increased plastics, birds may feel satiated and select prey that are easier to catch and will forage less often. Thus, I predicted smaller and fewer prey in Fulmars with greater amounts of plastic. Additionally, I identified prey to species taxa to test whether a shift to smaller prey also indicated a change from larger to smaller species eaten by fulmars had occurred. A natural shift of diet in Fulmars when prey availability is altered (Cherl et al. 2001; indicative of an opportunistic feeder) may complicate any shift in prey species selection with increasing plastic loads. Despite this shift, a change in the amount and size class of prey consumed should be observed when comparing birds with varying volumes of plastic debris. Because it is uncertain if fulmars of poor or healthy condition contain 
greater plastic loads, I predicted that fulmars of poor condition would have significantly greater plastic loads. Fulmar condition will be based on subcutaneous fat and pectoral muscle indices. Interannual differences in oceanic conditions also are important in determining which prey are available to fulmars.

Pelagic seabirds, including Northern Fulmars, forage over large spatial scales. Studies of prey of pelagic seabirds, therefore, provide natural indices of food web composition, location of prey, and relative abundance of prey among years in relation to oceanographic conditions (Montevecchi \& Myers 1996, Sydeman et al. 2001). Changes in prey selected by Northern Fulmars, therefore, may be in response to short-term fluctuations in prey abundance (Suryan et al. 2002). Discriminatory prey choice in some seabirds, however, also has been documented (i.e., some prey items were over or underrepresented, relative to their abundance; Suter 1997, Suryan et al. 2002).

The abundance and availability of cephalopods, the primary prey of fulmars, are influenced by variable oceanic conditions, prey movements, behavior, and life-cycle characteristics that are species-specific (Boyle \& Boletzky 1996, Rodhouse \& Nigmatullin 1996). Cephalopod beaks recovered from seabirds and other marine predators can be used to determine prey species and contribute to indirect population assessments of cephalopods and determine aggregation areas (Clarke et al. 1986, Boyle \& Boletzky 1996). If deeper-water cephalopods (e.g., Gonatidae) dominated Northern Fulmar diet, I predicted there would be no significant difference relative to oceanic conditions, because mesopelagic and deep-water squids should be less influenced by 
dynamic oceanic conditions than surface-dwelling squid (e.g. Dorytheuthis opalescens). Overall, I predicted that Fulmars carrying greater internal plastic loads would contain the least amount of cephalopods and the smallest size class of cephalopods regardless of oceanic conditions.

\section{Methods}

Northern Fulmars that washed ashore in the Monterey Bay area in 2003 and 2007 were collected by volunteer beach-walkers and later necropsied at the Marine Wildlife Veterinary Care and Research Center [California Department of Fish and Game, Santa Cruz, California (CDFG)]. One hundred eighty five dead fulmars were collected in 2003, and 111 dead (named SCD) and 74 live (named SCL) were collected in 2007. Those collected live died within one week and were then sampled. Carcasses were necropsied within $24 \mathrm{~h}$ of collection or frozen at $-20^{\circ} \mathrm{C}$ until 12 to $24 \mathrm{~h}$ before necropsy when they were thawed at room temperature. Morphometrics were determined for each bird (head length, bill depth at gonys, bill length, tarsus length, flattened wing chord were measured to the $\pm 1 \mathrm{~mm}$ ). Body condition indices were based on condition of the pectoral muscle and quantity of subcutaneous fat (van Franeker \& Meijboom 2002). Both indices were scored $0-3$, where 0 indicates total depletion and 3 is optimal condition. Additionally, pectoralis, liver, and stomach tissues were sampled (van Franeker \& Meijboom 2002 for

detailed protocol). Stomachs were dissected out by severing the esophagus at throat-level and at the intestine under the ventriculus. The stomachs were refrozen and processed at a later time. The sex and body condition of the birds were noted based on internal organ 
inspection. Body condition was an assessment of internal/external injuries while noting the presence or absence of fractures, internal bleeding, and bruising. For this study, sex and age class were referred to as demographics, while pectoral muscle index and subcutaneous fat indices were referred to as body condition.

Age estimates were based on the development of the sex organs (size, shape, and color) and the presence and size of the Bursa Fabricius. For males, testis length and width were measured $( \pm 1 \mathrm{~mm})$, and color was noted (dark, bi-colored, pink, or whitish). In females, ovary length and width and the diameter of the largest follicle were measured $( \pm 1 \mathrm{~mm})$. An oviduct development score (1 to 4 from juvenile to breeding adult) was assigned (Van Franeker \& Meijboom 2002). Age estimates were assigned as juvenile ( $1^{\text {st }}$ year), immature (incomplete development of sex organs; estimated 2-6 years old), and adult (organs show signs of previous breeding or full capability to breed; van Franeker \& Meijboom 2002). The presence and size of the Bursa of Fabricius was noted; it was assumed that only juvenile and immature birds $(\leq 1$ year) contained prominent bursas (van Franeker \& Meijboom 2002).

Stomachs were processed after necropsy of the fulmars. The proventriculus and ventriculus later were thawed and processed separately for the 2007 samples. The proventriculus was severed from the ventriculus and both were weighed before dissection, opened full length, flushed with water to collect contents, and weighed after dissection (van Franeker \& Meijboom 2002). Flushed particles were collected in a 0.5 mm mesh sieve and rinsed to remove prey soft tissues. Hard parts, plastics, and other 
remaining non-food hard particles were collected from the sieve and placed in a segregated Petri dish; (the 2003 samples were previously processed by MLML students) and the stomach contents were saved in glass vials where plastics, parasites, and cephalopod beaks were stored separately. I separated the plastics into segregated Petri dishes, following the protocol of van Franeker \& Meijboom (2002), for further processing and analyses. A binocular microscope was used to separate items into specified categories (prey, natural items, user plastics, industrial plastics, etc.). Cephalopod beaks were placed separately in small Nalgene or glass vials and saturated in $70 \%$ isopropyl alcohol to prevent drying.

Once separated, the plastics were quantified by frequency of occurrence, number of particles, total mass, and relative mass compared with proportion of other matter in stomach. Plastics were dried, weighed, counted, and categorized for each sample (van Franeker \& Meijboom 2002). The primary plastic categories for my study were industrial plastics (pre-molded pellets used in manufacturing), user plastics (all nonindustrail remains of plastic objects such as sheet-like plastics, threads, rubbers, and foam), all plastic (both industrial and user), and all debris (includes all plastics and other non-plastic man-made debris and chemicals).

Fish otoliths were eliminated from the analyses due to extensive degradation ( $>$ 10 total, they crumbled when touched with forceps). Cephalopod beaks were examined using a dissecting scope, measured with digital calipers, and identified to lowest taxonomic level using physical descriptions, reference collections, and literature sources 
(Clarke et al. 1986, William Walker unpublished beak guide illustrations 2009, National Marine Fisheries Service, National Marine Mammal Laboratory, Seattle reference collection). Lower cephalopod beaks were measured to the nearest $0.1 \mathrm{~mm}$. Estimated dorsal mantle length (DML) and mass of the cephalopod prey were determined using the lower beak rostral length (LRL) measurements and published regression equations (Wolff 1984, Clarke et al. 1986, Walker in press). Based on species and beak size, the cephalopods were categorized as surface-dwelling, mesopelagic, or deep-sea squids.

To examine how oceanic conditions might influence foraging, oceanic conditions and fulmar tracking were examined using published sources. I used California Cooperative Oceanic Fishery Investigations (CalCOFI) reports to examine inshore and offshore changes of abiotic and biotic factors in the California Current System (CalCOFI Rep. Vol 45-50). Fulmars sampled from 2003 were grouped as "warm-water," and those sampled from 2007 were grouped as "cold-water." This was based on CalCOFI reports that El Niño-like conditions occurred during 2003 and La Niña conditions occurred during 2007 (CalCOFI Rep. Vol 45-49). Fulmar foraging areas were predicted using tracking data from previously tagged fulmars from Alaskian colonies in 2002 and 2003 (Hatch et al. 2010).

\section{Statistics}

Initially, cephalopod prey items were analyzed separately from plastic items. I described feeding strategy and diet diversity using a modified version of the Costello Method and the Shannon-Wiener diversity index (Amundsen et al. 1996, Zar 1999). The 
Amundsen modification to the Costello Method plots the prey-specific abundance, \%PN, against the frequency of occurrence, $\mathrm{FO}$ (expressed in fraction rather than in percent). The modification "allows prey importance, feeding strategy and the inter- and intraindividual components of niche width" to be examined (Amudsen et al. 1996, Fig. 1). Prey-specific abundance was defined as:

$$
\mathrm{P}_{\mathrm{i}}=\left(\sum \mathrm{S}_{\mathrm{i}} / \sum \mathrm{S}_{\mathrm{t}}\right) * 100
$$

where $\mathrm{P}_{\mathrm{i}}$ is the prey-specific abundance of prey $i, \mathrm{~S}_{\mathrm{i}}$ is number of prey $i$, and $\mathrm{S}_{\mathrm{t}}$, the total number of items in the stomach only for those predators with prey $i$ in their stomach (Amudsen et al. 1996). The Shannon-Wiener diversity $\left(H^{\prime}\right)$ index measures diversity in categorical data using the number and evenness of the species. Greater species evenness or the addition of more species increases the index that is defined as

$$
H^{\prime}=-\sum_{i=1}^{s}(p i \ln p i)
$$

where $p_{i}$ is the relative abundance of each species calculated as the number of species $\left(\mathrm{n}_{\mathrm{i}}\right)$ divided by the total number of individuals $(\mathrm{N})$ evaluated for all species (s). 


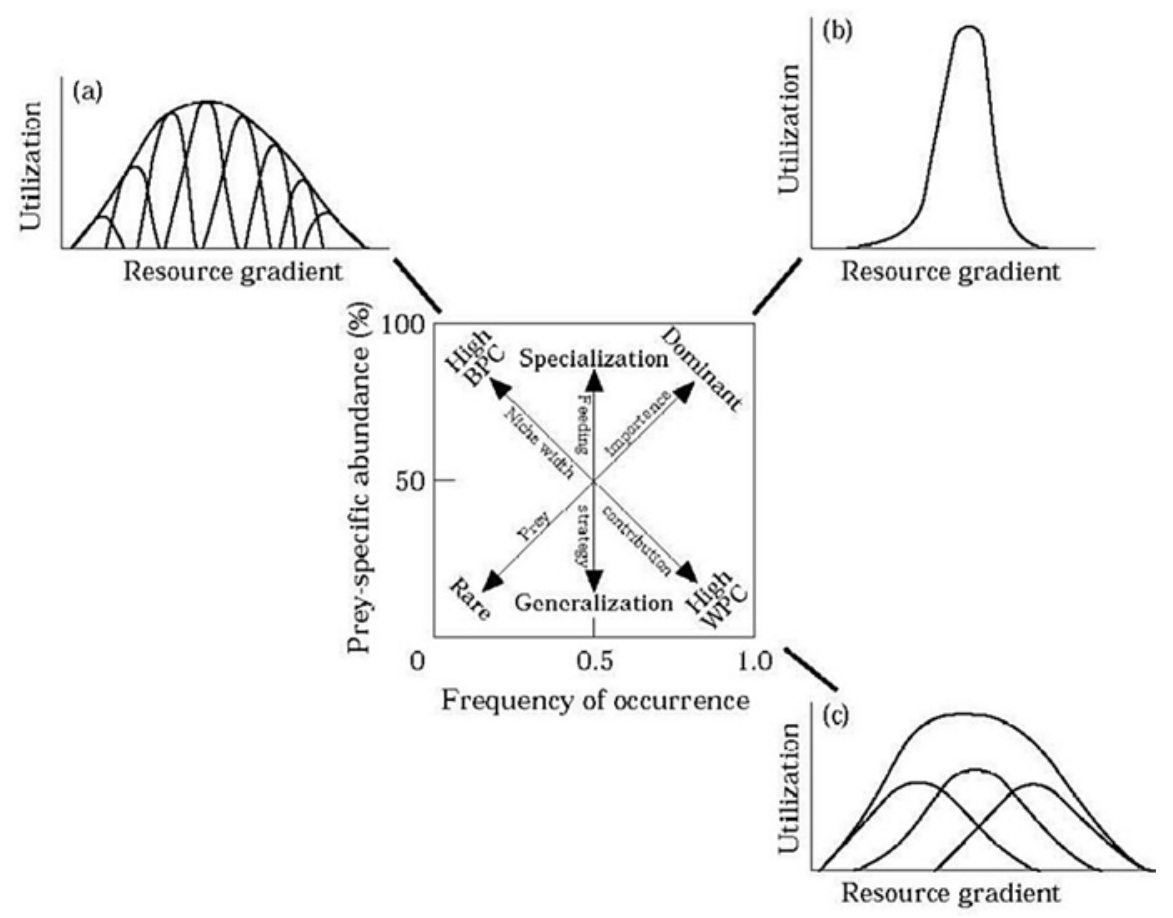

Figure 1. Graphical analysis of feeding strategy diagram reprinted from Costello et al. 1996 indicating interpretation of feeding strategy, niche width contribution, and prey importance, and characteristic niche curves. (a) High between-phenotype component to niche width, (b) narrow niche width, and (c) high with-in phenotype component.

Estimates of dorsal mantle length (DML) and mass of cephalopods were plotted in frequency histograms. Multivariate Analysis of Variance (MANOVA with 9999 permutations) tested for differences in prey and plastics between the two years, the sexes, the ages classes (juveniles versus adults), and body conditions (healthy versus poor) 
using R Enterprise Statistical Software. Because the majority of Fulmars were of poor condition in 2003 and there was not equal representation of healthy birds, both indices representing bird condition were removed from the analysis for with-in year comparisons.

Basic statistics were performed on the total number and mass of four plastic categories (total marine debris, all plastic, industrial plastic, and user plastics). The plastic data were $\ln$ transformed, and Analysis of Variance (ANOVA) tested for differences in the plastic categories between years. A Bonferroni correction was used to address the issue of multiple comparisons. Multivariate Analysis of Variance (MANOVA with 9999 permutations) tested for differences in plastic categories between the two years, sexes, age classes, and body conditions using R Software.

Finally, the prey items and plastic items were analyzed together. Canonical correlation analysis tested for correlations between the number and masses of the plastic compared with the number and size of prey species for each of the two years fulmars were collected (personal comm. Bros 2009). Only the user and industrial plastic categories were used in this analysis to eliminate some of the multicollinearality associated with total marine debris and total plastic categories. 


\section{Results}

Demographics and body condition indices revealed the sex, age group, subcutaneous fat index, and pectoral muscle index between both years; 2003 with mostly 0-1 indices and 2007 with a range of 0-3 indices (Table 1). The sex ratio was 50:50 in 2003 (for those in which sex could be identified; Nevins \& Harvey 2005), but there were almost a third as many males as females in 2007 (Table 1). Both years were dominated by immature birds with lesser subcutaneous fat and lesser pectoral muscle indices indicating most birds were young and of poor health (Table 1). 
Table 1

Number of demographic measurements and body condition indices recorded for the Northern Fulmar samples collected in 2003 and 2007

\begin{tabular}{lrr}
\hline Demographics & $\mathbf{2 0 0 3}$ & $\mathbf{2 0 0 7}$ \\
\hline Sex & 68 & 63 \\
Female & 67 & 113 \\
Male & 43 & 9 \\
Unknown & & \\
Age Group & 145 & 164 \\
Immature & 0 & 18 \\
Adult & 33 & 3 \\
Unknown & & \\
& & \\
Body Condition I ndices & & 125 \\
SubQ Fat Index & 141 & 38 \\
0 & 0 & 12 \\
1 & 0 & 3 \\
2* & 0 & 7 \\
3* & 37 & \\
Unknown & & 51 \\
Pec Muscle I ndex & 0 & 95 \\
0 & 140 & 27 \\
1 & 0 & 4 \\
2* & 0 & \\
3* & 38 & \\
Unknown & & \\
$*$ indicates 'healthy' code & &
\end{tabular}

Note. Subcutaneous fat is represented by "SubQ Fat Index" and pectoral muscle by "Pec Muscle Index."

Diets were similar between years, but there were significant differences in the number of cephalopods eaten between years. The average number of beaks in $2007(\overline{\mathrm{x}}=$ $3.5, \mathrm{SE}=3.36$, range $=0-15)$ was significantly greater $(\mathrm{P}=0.03)$ than in $2003(\overline{\mathrm{x}}=2.7$, $\mathrm{SE}=3.03$, range $=0-13$ ). I identified 1065 cephalopod beaks (542 for 2003; 523 for 
2007) from fulmar stomachs. Fulmar diet was dominated by mesopelagic cephalopods of the family Gonatidae in both years (Table 2). 


\section{Table 2}

\section{Occurrence (number of beaks) and zone distribution of identified cephalopods (family}

and species) from the stomachs of Northern Fulmar in 2003 and 2007

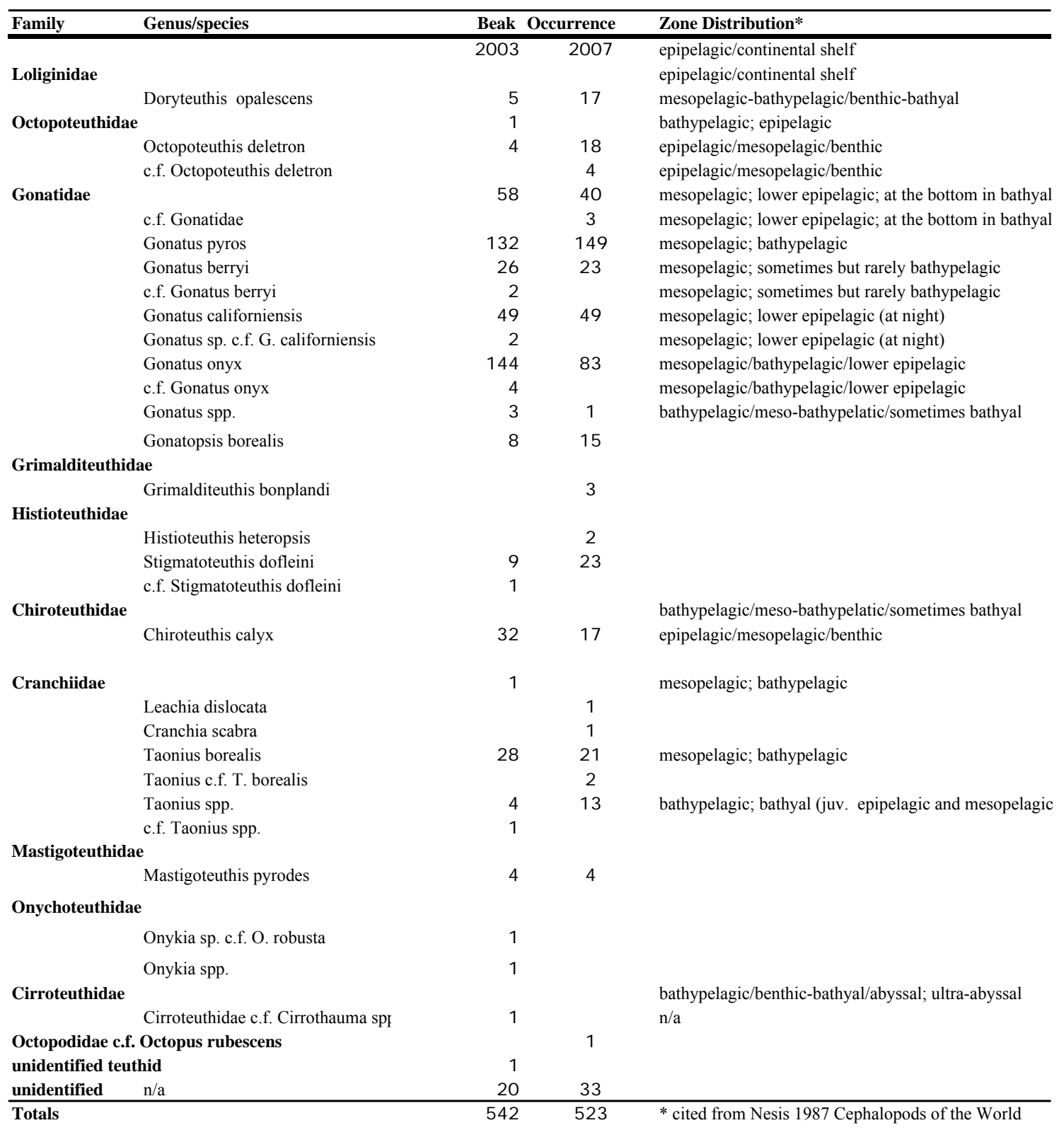


The dominant species were Gonatus onyx, Gonatus pyros, and Gonatus californiensis (Table 2). Shannon-Wiener Diversity Index values of 246 for 2003 and 226 for 2007 are representative of an abundant and diverse prey community that is evenly distributed (Zar 1999). A subset of 931 beaks were suitable for measurement (474 for 2003; 457 for 2007). The average LRL was $3.76 \mathrm{~mm}(\mathrm{SE}=0.04)$ in 2003 and $3.80 \mathrm{~mm}$ $(\mathrm{SE}=1.06)$ in 2007 , which were not significantly different between years. Finally, histograms of the regressed dorsal mantle lengths and masses revealed similar size classes of cephalopods were eaten between the sampled years (Figs. 2, 3). 
G. pyros 2003

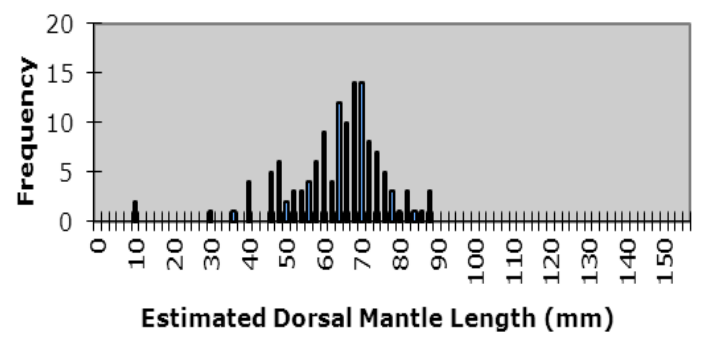

G. californiensis 2003

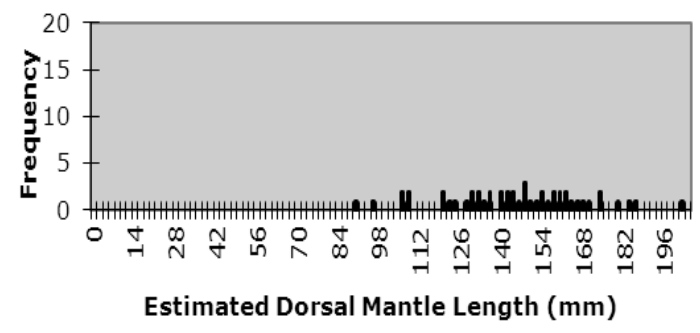

G. onyx 2003

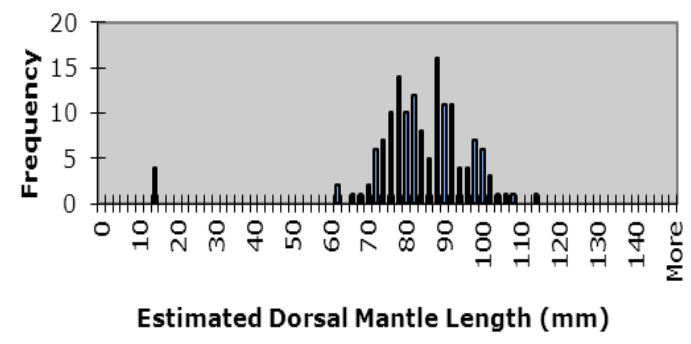

G. pyros 2007

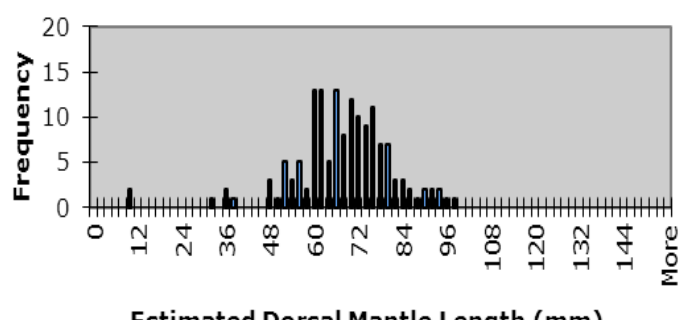

G. californiensis $\mathbf{2 0 0 7}$

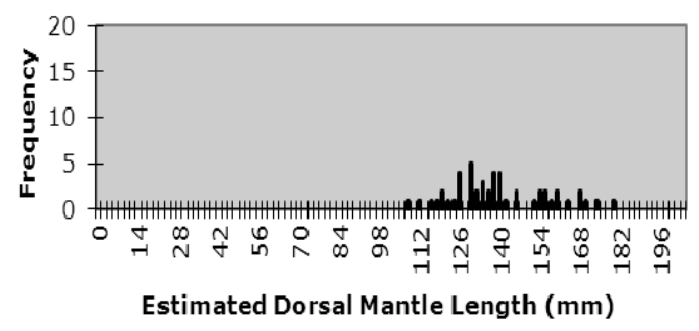

G. onyx 2007

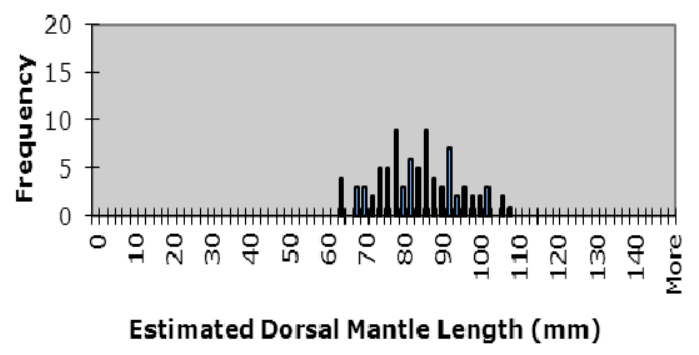

Figure 2. Distribution of estimated dorsal mantle lengths (mm) for Gonatus pyros, $G$. californiensis, and G. onyx in 2003 and 2007. Regressions were used from Wolff 1984, Clarke et al. 1986, and Walker in press. 
G. pyros 2003

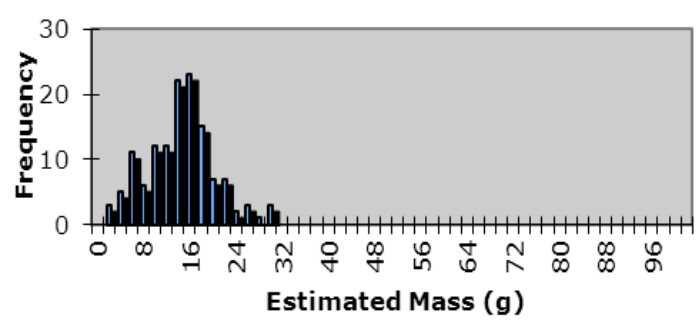

G. californiensis 2003

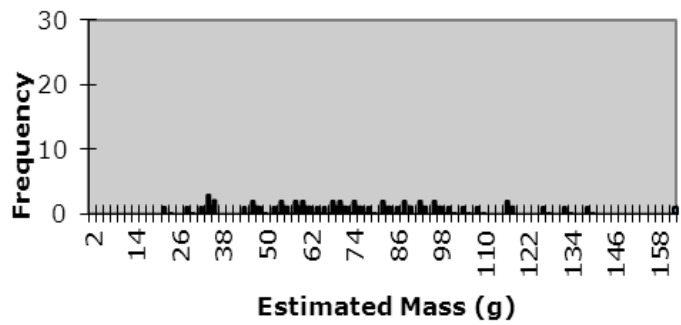

G. onyx 2003

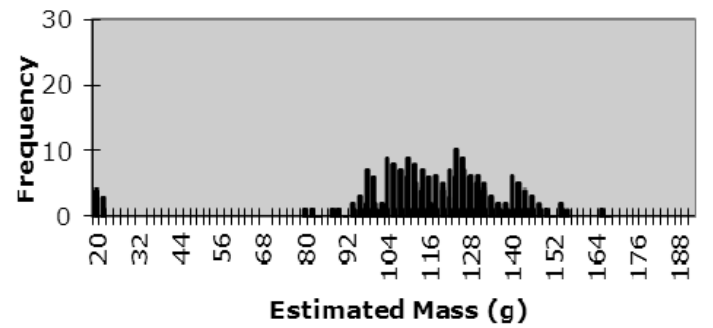

G. pyros 2007

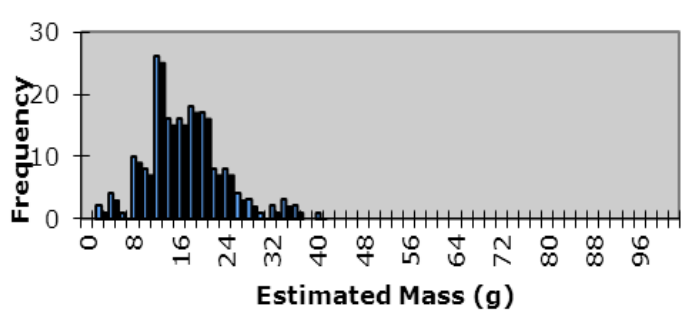

G. californiensis $\mathbf{2 0 0 7}$

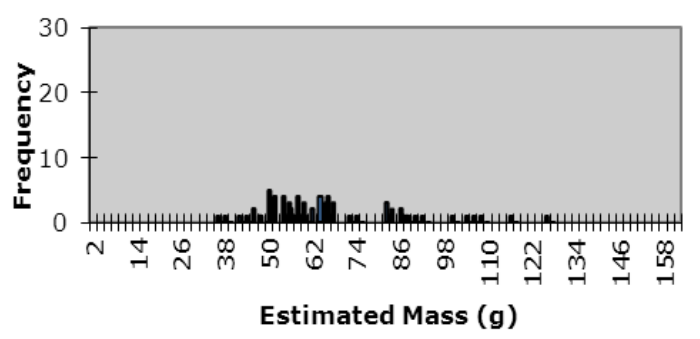

G. onyx 2007

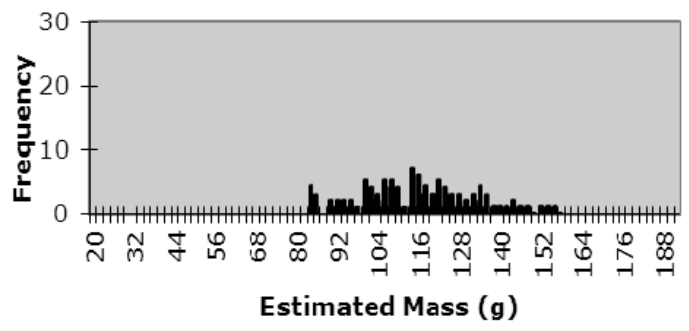

Figure 3. Frequency distribution of estimated masses (g) for Gonatus pyros, G.

californiensis, and G. onyx in 2003 and 2007. Regressions were used from Wolff (1984), Clarke et al. (1986), and Walker (in press). 
In addition to prey importance, the modified Costello plots represent the feeding strategy of fulmars. Most of the prey items fall in the middle of the plots indicating a generalist foraging strategy and a broad niche width (Fig. 4). Prey items that fall in either "the upper left or lower right corner represent prey types that make the same overall contributions to the population diet, but they are indicative of totally different feeding strategies of individual predators" (Amudsen et al. 1996). In this case, no prey items fall in the upper right hand of the diagrams, indicating no specialization of fulmars (Amundsen et al. 1996). However one prey item, Doryteuthis opalescens (commonly called Market Squid), falls in the upper left-hand corner indicating specialization of individual Fulmars when that prey item was available (Fig. 4). Overall, the Fulmars encountered Gonatid squids more than other taxa. Furthermore, the plots indicate a great within-phenotype component with most of the fulmars using many resource types at the same time (Figs.1, 4). 

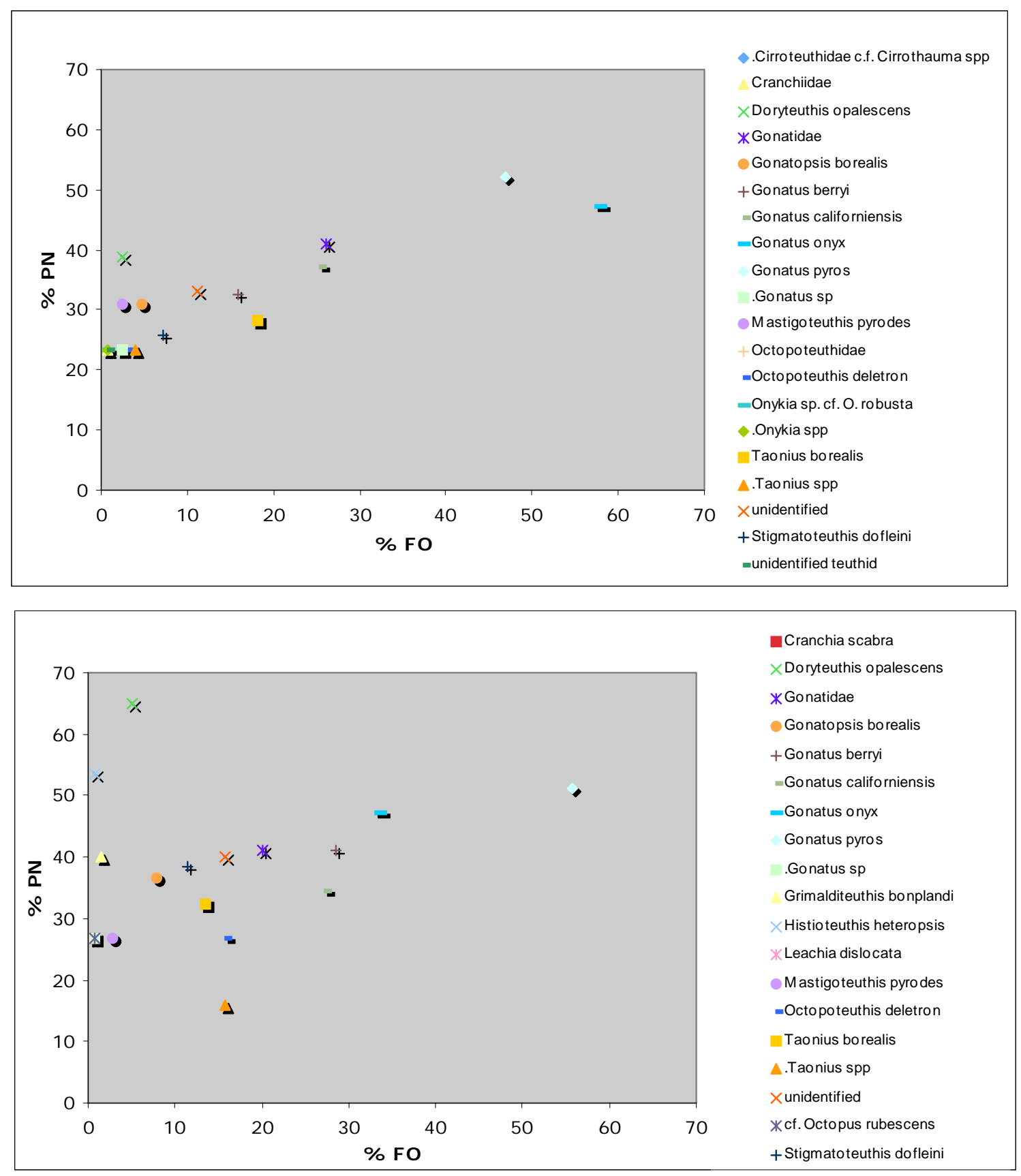

Figure 4. Modified Costello plots (adapted from Amudsen et al. 1996) of identified cephalopods from the Northern Fulmars for 2003 (top) and 2007 (bottom). 
In testing for prey differences between years the MANOVA indicated a significant, positive relationship between body condition (pectoral muscle index) and the number (intercept -0.73) and average LRL of cephalopod beaks per stomach (intercept $-0.33, \mathrm{P}=0.02$; Table 3 ). Where a lesser pectoral muscle index (unhealthy muscle biomass) indicated a lesser number and average LRL of beaks. No significant differences were found in the demographics (sex, age group) or the other body condition variable (subcutaneous fat; Table 3). 
Table 3

MANOVA comparisons of prey variables (number and average lower rostral lengths (mm) of cephalopod beaks per stomach) versus the demographics and body condition indices of Northern Fulmar samples between years and within years (2003 and 2007)

\begin{tabular}{|c|c|c|c|c|c|c|c|}
\hline \multicolumn{8}{|c|}{ Both Years Prey Variables vs. Demographics o } \\
\hline & $\mathrm{DF}$ & Pillai & Approx F & num DF & den DF & \multicolumn{2}{|l|}{$\operatorname{Pr}(>F)$} \\
\hline$\overline{\mathrm{SEX}}$ & 1 & 0.02 & 1.80 & 2 & 215 & 0.17 & \\
\hline AGE_GROUP & 1 & 0.00 & 0.40 & 2 & 215 & 0.67 & \\
\hline $\mathrm{PEC}^{-} \mathrm{CODE}$ & 1 & 0.03 & 3.82 & 2 & 215 & $0.02 *$ & \\
\hline SUBQ FAT & 1 & 0.01 & 0.58 & 2 & 215 & 0.56 & \\
\hline YEAR & 1 & 0.02 & 2.25 & 2 & 215 & 0.11 & \\
\hline \multicolumn{8}{|c|}{2007 Prey Variables vs. Demographics or Body Condition } \\
\hline & DF & Pillai & Approx F & num DF & den DF & $\operatorname{Pr}(>\mathrm{F})$ & \\
\hline SEX & 1 & 0.02 & 1.37 & 2 & 173 & 0.26 & \\
\hline AGE_GROUP & 1 & 0.00 & 0.23 & 2 & 173 & 0.80 & \\
\hline $\mathrm{PEC}^{-} \mathrm{CODE}$ & 4 & 0.04 & 0.98 & 8 & 348 & 0.45 & \\
\hline SUBQ_FAT & 4 & 0.04 & 0.88 & 8 & 348 & 0.53 & \\
\hline \multicolumn{8}{|c|}{2003 Prey Variables vs. Demographics or Body Condition } \\
\hline & DF & Pillai & Approx F & num DF & den DF & $\operatorname{Pr}(>F)$ & $\operatorname{Pr}(>F)$ \\
\hline SEX & 1 & 0.07 & 5.30 & 2 & 149 & $0.01 * *$ & $0.30 * * *$ \\
\hline AGE GROUP & 1 & 0.03 & 2.32 & 2 & 149 & 0.10 & \\
\hline
\end{tabular}

** with unknown, female, males

*** female vs. males

Note. The demographics are sex and age group (AGE_GROUP); the body condition indices pectoral muscle (PEC_CODE), and subcutaneous fat (SUBQ_FAT). The Pillai value (Pillai), approximate F value (Approx F), degrees of freedom of the numerator (num DF), degrees of freedom of the denominator (den DF), and the two-tailed significance probability $[\operatorname{Pr}(>\mathrm{F})]$. Comparison with a significant difference marked by an asterisk $(*)$. 
When examining prey difference with-in years, however, the results differed. There were no significant differences in any of the explanatory variables for 2007 (sex, age group, subcutaneous fat, pectoral code) for number and average LRL of cephalopod beaks per stomach (Table 3). There was a significant difference in 2003 between sexes for number and average LRL of cephalopod beaks per stomach when the subcutaneous and pectoral indices were removed. It was deemed appropriate to remove those variables for the 2003 analysis because all fulmars were in 'poor' condition (Table 1; Table 3).

There were differences in some categories of ingested plastics in Fulmars. In 2003, 45 of the 178 samples (25\%) did not have any form of plastic, whereas in 2007 only 4 of 185 samples (2\%) had no plastic. Incidence of total plastic was $75 \%$ in 2003 and $98 \%$ in 2007. Overall, the mean number and mass of the plastic categories were greater in 2007 than in 2003 (Table 4). In 2007, there was a significant increase in the $\ln$ transformed mass of the user plastic category between Fulmars collected live (SCL; $\overline{\mathrm{x}}=$ $0.231 ; \mathrm{SE}=0.03)$ and dead $(\mathrm{SCD} ; \overline{\mathrm{x}}=0.227 ; \mathrm{SE}=0.06)$ as a result of greater variance in the SCD samples $\left(\sigma^{2}=0.43\right)$ versus the SCL samples $\left(\sigma^{2}=0.07\right)$. There were no significant differences in the other plastic categories. Therefore, the rest of the plastic categories for 2007 were pooled for comparisons with 2003 samples, whereas the $\ln$ transformed mass of user plastics was analyzed in two steps (SCL vs. 2003 and SCD vs. 2003; Table 5). Because the majority of SCL fulmars died within hours to one week of collection, it was deemed appropriate to compare the SCL and SCD groups. The number 
and mass of the four plastic categories were compared between the two years. Significant differences between years were found in the following categories: number and mass of marine debris, number and mass of all plastic, and number of user plastic pieces (Table 6). Significant differences also were found between the SCL vs. 2003 and SCD vs. 2007 masses of user plastics (Table 6).

Table 4

Mean and Standard Errors (SE) of number and masses ( $g$ ) of marine debris, all plastic, industrial plastic, and user plastic categories for the 2003 and 2007 samples

\begin{tabular}{lcr} 
& 2003 & \multicolumn{1}{c}{2007} \\
\cline { 2 - 3 } Category & Mean SE & \multicolumn{1}{c}{ Mean SE } \\
\hline N_Mar-Debris & 9.200 .68 & 24.051 .77 \\
N_Plastic-All & 8.980 .66 & 22.241 .63 \\
N_Plastic-Ind & 1.370 .10 & 1.430 .11 \\
N_Plastic-User & 6.560 .48 & 12.440 .91 \\
G_Mar-Debris & 0.150 .01 & 0.570 .04 \\
G_Plastic-All & 0.150 .01 & 0.470 .03 \\
G_Plastic-Ind & 0.030 .00 & 0.030 .00 \\
G_Plastic-User & 0.110 .01 & 0.230 .02 \\
\hline
\end{tabular}


Table 5

Multivariate Analysis of Variance (MANOVA) comparisons of demographics and body condition indices versus the number and masses $(\mathrm{g})$ of all the plastic categories for the Northern Fulmar samples for 2003 and 2007

\begin{tabular}{lccccrr}
\hline \multicolumn{7}{c}{ Both Years Demographics or Body Condition vs. Plastic Masses } \\
& DF & Pillai & Approx F & num DF & den DF & $\operatorname{Pr}(>$ F $)$ \\
\hline SEX & 1 & 0.00 & 0.28 & 4 & 297 & 0.89 \\
AGE_GROUP & 1 & 0.00 & 0.33 & 4 & 297 & 0.86 \\
PEC_CODE & 1 & 0.01 & 0.43 & 4 & 297 & 0.79 \\
SUBQ_FAT & 1 & 0.03 & 2.28 & 4 & 297 & 0.06
\end{tabular}

Both Years Demographics or Body Condition vs. Plastic Number

\begin{tabular}{lccccrrr} 
& DF & \multicolumn{2}{l}{ Pillai Approx F } & num DF & den DF & $\operatorname{Pr}(>\mathrm{F})$ \\
\hline SEX & 1 & 0.00 & 0.27 & 4 & 297 & 0.90 \\
AGE_GROUP & 1 & 0.01 & 0.74 & 4 & 297 & 0.56 \\
PEC_CODE & 1 & 0.02 & 1.78 & 4 & 297 & 0.13 \\
SUBQ_FAT & 1 & 0.05 & 3.52 & 4 & 297 & $0.01 *$
\end{tabular}

2007 Demographics or Body Condition vs. Plastic Masses

\begin{tabular}{|c|c|c|c|c|c|c|}
\hline & $\mathrm{F}$ & Pillai & $x \mathrm{~F}$ & num DF & den DF & $\operatorname{Pr}(>F)$ \\
\hline SEX & 1 & 0.04 & 1.79 & 4 & 163 & 0.13 \\
\hline AGE_GROUP & 1 & 0.36 & 1.54 & 4 & 163 & 0.19 \\
\hline PEC_CODE & 4 & 0.15 & 1.67 & 16 & 664 & $0.05 *$ \\
\hline SUBQ_FAT & 3 & 0.03 & 0.47 & 12 & 495 & 0.93 \\
\hline
\end{tabular}

2007 Demographics or Body Condition vs. Plastic Number

\begin{tabular}{|c|c|c|c|c|c|c|}
\hline & $\mathrm{F}$ & Pillai & $x \mathrm{~F}$ & num DF & den DF & $\operatorname{Pr}(>F)$ \\
\hline SEX & 1 & 0.02 & 0.85 & 4 & 163 & 0.49 \\
\hline AGE GROUP & 1 & 0.02 & 0.76 & 4 & 163 & 0.55 \\
\hline PEC_CODE & 4 & 0.10 & 1.09 & 16 & 664 & 0.36 \\
\hline SUBQ_FAT & 3 & 0.07 & 0.98 & 12 & 495 & 0.47 \\
\hline
\end{tabular}

2003 Demographics or Body Condition vs. Plastic Masses

\begin{tabular}{|c|c|c|c|c|c|c|}
\hline & $\mathrm{F}$ & Pillai & & num DF & den DF & $\operatorname{Pr}(>F)$ \\
\hline SEX & 1 & 0.02 & 0.86 & 4 & 170 & 0.49 \\
\hline AGE GROUP & 1 & 0.02 & 0.74 & 4 & 170 & 0.57 \\
\hline
\end{tabular}

2003 Demographics or Body Condition vs. Plastic Number

\begin{tabular}{|c|c|c|c|c|c|c|}
\hline & $\mathrm{DF}$ & Pillai & & num DF & den DF & $\operatorname{Pr}(>F)$ \\
\hline SEX & 1 & 0.02 & 0.89 & 4 & 170 & 0.47 \\
\hline AGE_GROUP & 1 & 0.01 & 0.55 & 4 & 170 & 0.70 \\
\hline
\end{tabular}


Note. Sex, age group (AGE_GROUP), pectoral muscle (PEC_CODE), and subcutaneous fat (SUBQ_FAT) are shown for both years, 2007, and 2003. The Pillai value (Pillai), approximate F value (Approx F), degrees of freedom of the numerator (num DF), degrees of freedom of the denominator (den DF), and the two-tailed significance probability [Pr $(>\mathrm{F})$ ]. Comparisons with significant differences are marked by asterisks $\left(^{*}\right)$.

Table 6

Analysis of Variance (ANOVA) results of the In transformed plastic categories where the number and the masses ( $g$ ) for the 2003 and 2007 fulmars of the following categories were compared: marine debris, all plastic, industrial plastic, and user plastic

\begin{tabular}{lccc}
\hline & DF & t & p-value \\
\hline InN_Mar-Debris & 336 & 7.98 & $<0.001^{*}$ \\
InN_Pla-All & 336 & 7.50 & $<0.001^{*}$ \\
InN_Pla-Ind & 336 & 0.83 & 0.407 \\
InN_Pla-User & 336 & 6.29 & $<0.001^{*}$ \\
InG_Mar-Debris & 336 & 6.41 & $<0.001^{*}$ \\
InG_Pla-All & 336 & 5.66 & $<0.001^{*}$ \\
InG_Pla-Ind & 336 & 1.20 & $0.231^{*}$ \\
InG_PlaUser & & & \\
SCL vs. 2003 & 225 & 5.09 & $<0.001^{*}$ \\
SCD vs. 2003 & 262 & 3.02 & $0.003^{*}$ \\
\hline
\end{tabular}

* indicates significant value

Note. Significant differences between years are asterisked $(*)$.

The results of the MANOVA indicated number and masses of the plastic categories differed with body condition. There appeared to be a relationship between number of plastics and subcutaneous fat when both years were examined, but this is 
likely due to the overwhelming number of birds of 'poor' condition in 2003 (Table 5). When years were examined separately, there was a significant, negative relationship in 2007 between pectoral muscle index and mass of total marine debris, where greater pectoral mass indicated lesser masses of debris (Table 5). There were no differences found for 2003 (with and without the removal of the subcutaneous and pectoral indices; Table 5).

Finally, the Canonical Correlation Analyses indicated there were no significant correlations between the number and mass of plastic compared with the number and size of prey species for each of the two years (Table 7). The graph suggests that, although not significant, there is a negative correlation between the mass of user plastics (Var Y4) and the average LRL per stomach (Var X2) indicated by the vectors pointing in opposite directions (Fig. 5).

Table 7

Canonical Correlation Analysis correlations between number and mass ( $g$ ) of the plastic (industrial and user categories) compared with the number and average Lower Rostral Length (mm) of cephalopod beaks per stomach for 2003, 2007, and both years pooled

\begin{tabular}{|c|c|c|c|}
\hline \multirow[t]{2}{*}{ Category } & \multirow[t]{2}{*}{ P Value } & \multicolumn{2}{|c|}{ Canonical Correlations } \\
\hline & & CanAxis1 & CanAxis2 \\
\hline 2003 & 0.60 & 0.19 & 0.08 \\
\hline 2007 & 0.79 & 0.14 & 0.08 \\
\hline both years & 0.63 & 0.11 & 0.08 \\
\hline
\end{tabular}



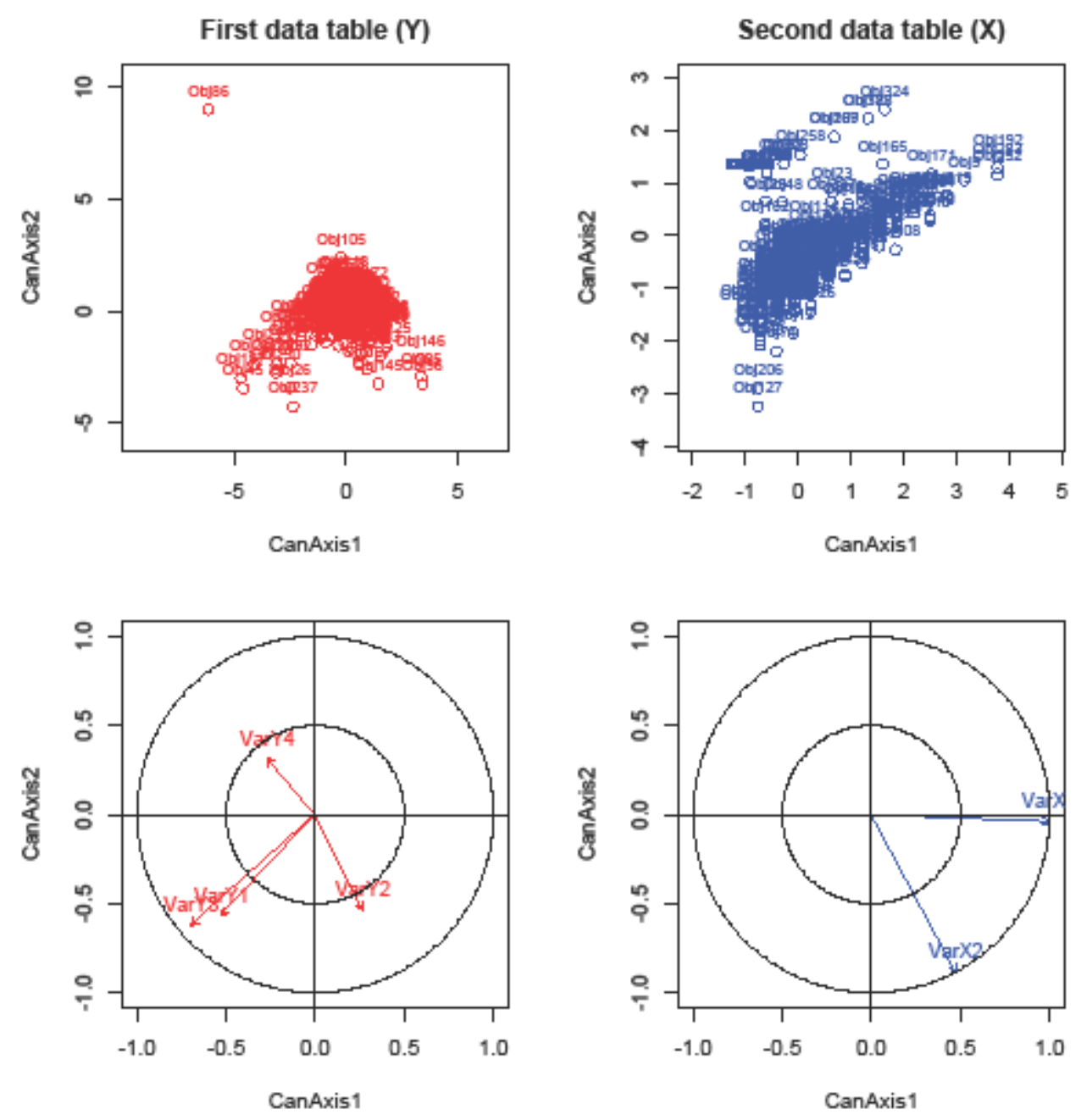

Figure 5. Canonical Correlation Analysis of the plastic variables (red) and cephalopod beak variables (blue). The top left indicates the grouping of all the plastic variables (number and mass) within the samples, whereas the bottom left indicates the vectors of the variables that have been created by the Eigenvalues (Var Y1: number of industrial plastic, Var Y2: number of user plastic, Var Y3: grams of industrial plastic, Var Y4: grams of user plastic; Fig. 6). The top right shows the grouping of the prey variables and 
the bottom right indicates the vectors (Var X1: number of beaks, Var X2: average LRL per stomach).

\section{Discussion}

The samples from this study represent a subset of the Pacific Northern Fulmar population that migrated to Monterey Bay that was mostly starving, immature, and in poor body condition. The demographics differed slightly, represented by both sexes in 2003, but was predominately male in 2007. Why the fulmars beached is most likely different for each year, as evidenced by difference in body condition and demographics. The fulmars in 2007 were part of the Santa Cruz "Mystery Spill" that initially was considered a clear, petroleum product, but instead was determined to be a non-toxic harmful algal bloom (HAB) of dinoflagellate species (Akashiwo sanguinea). This dinoflagellate produced a foam-like substance (Mycosporine-like amino acid) that caused extensive feather fouling and waterproof issues in affected seabirds (Jessup et al. 2009). Both adult and immature birds in poor and healthy condition were observed, but immature fulmars in poor body condition were the majority of the samples. Fulmars in better body condition may have been able to withstand the issues associated with the $\mathrm{HAB}$ or were perhaps able to avoid it completely. In the event, it was hypothesized that fulmars in 2003 were birds that originated from colonies in the Gulf of Alaska (Semidi Islands), based on color morph (predominately dark) and satellite telemetry (Hatch 1991; Nevins \& Harvey 2005; Hatch et al. 2010). Persistent storms in the winter of 2003 may have reduced their prey availability and prevented foraging (Nevins \& Harvey 2005). 
Lethargic, sick, and dead fulmars were observed offshore over the north shelf of Monterey Bay during at-sea surveys, many of these birds likely turned up dead on Monterey beaches (Nevins \& Harvey 2005).

During 2002-04, satellite tags were used to track the migration routes of fulmars from the North Pacific breeding sites to the wintering waters (Hatch et al. 2010). Three of the four tagged birds from the Semidi Islands migrated to the California Current System (CCS) off Washington, Oregon, and California and remained over neritic waters of the continental shelf (Hatch et al. 2010; Fig. 6a, b). Based on the tracked fulmars, I assumed that fulmars that were beach-cast in Monterey Bay during 2003 likely came from the Gulf of Alaska and followed similar foraging paths down the coast. 
(a) Gonatus californiensis

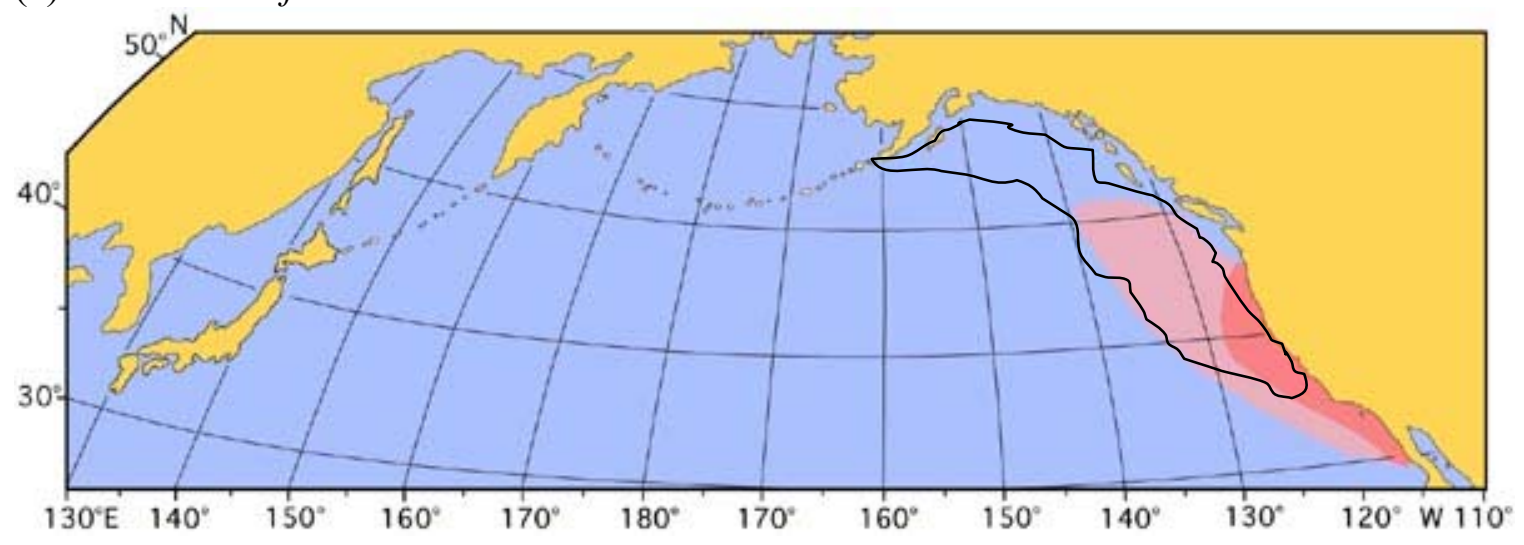

(b) Gonatus onyx

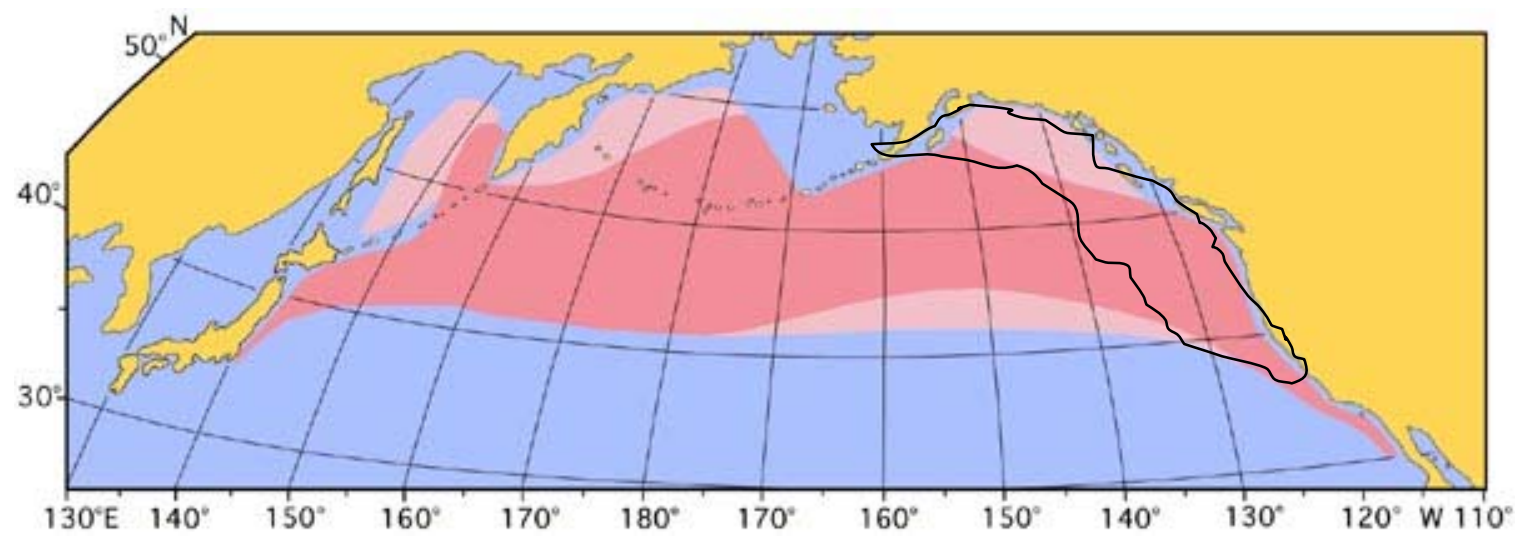

(c) Gonatus pyros

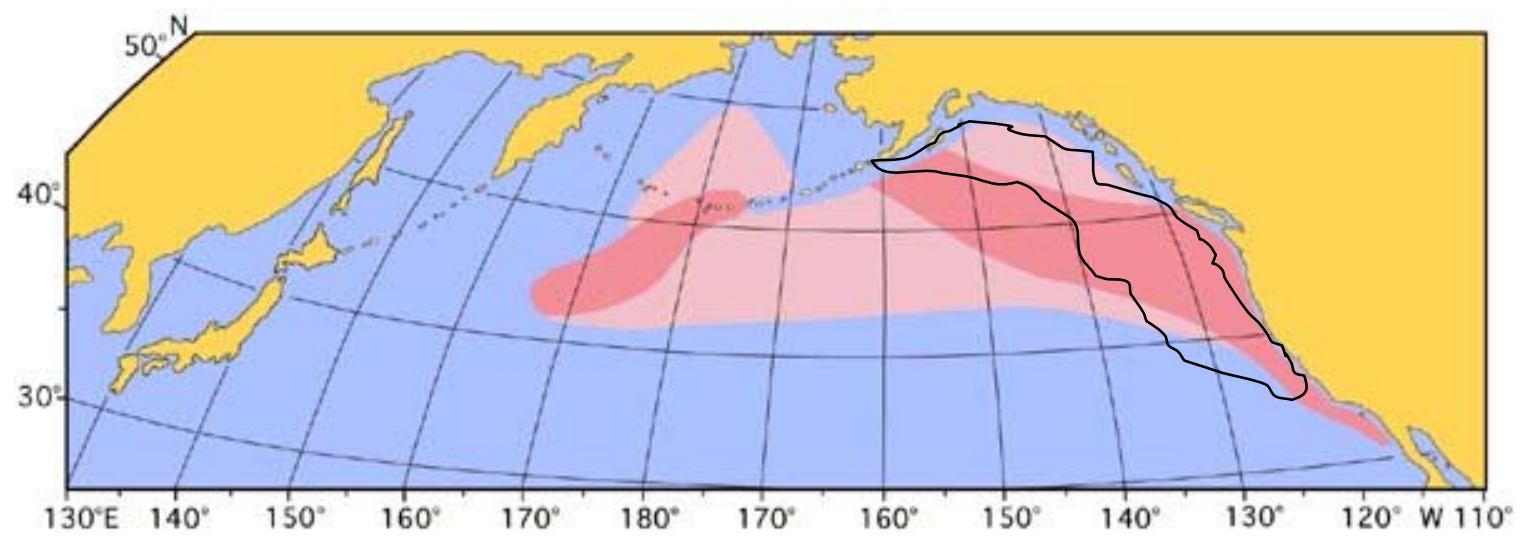


Figure 6. Distributions of the three dominant cephalopod species (a) Gonatus californiensis, (b) G. onyx, and (c) G. pyros in the 2003 and 2007 Northern Fulmar stomach samples. The dark pink regions indicate the known range and the light pink areas indicate the estimated range (Okutani et al. 1988 as cited in Tree of Life Web Project http://tolweb.org/tree/phylogeny.html). Black lines represent estimated foraging areas of fulmars (modified from Hatch et al. 2010). 
The CalCOFI report for 2003 noted that most of the North Pacific had weakly warm anomalies (from September 03-April 04) indicating a weak to moderate El Niño and positive Pacific Decadal Oscillation (PDO; CalCOFI Rep. Vol. 45). Oceanic trends included unusually strong upwelling throughout the CCS in summer, and strong downwelling in winter off northern California, Oregon, and Washington. Winds over the CCS in summer were persistently to the south (north winds), but strong fluctuations and reversals occurred almost monthly. Other trends were: an increase in southern California sea surface temperatures (SSTs), little or no change in chlorophyll $a$ concentrations, no dramatic changes in zooplankton biomass or community structure, and a shift in seabird community structure from temperate cold-species to sub-tropical species. It is likely that these oceanographic features were present when Fulmars were migrating down the coast in 2003.

The CalCOFI report for 2007 noted that a moderate-to-strong La Niña developed by the summer of 2007 (after moderate El Niño conditions in 2006-07) and a negative PDO (CalCOFI Rep. Vol. 49). There were strong north coastal winds with strong upwelling in 2007. The La Niña conditions contributed to average or above-average productivity with the following trends: below normal SSTs in the CCS, above normal chlorophyll $a$ concentrations, increased zooplankton biomass off Baja and Oregon (but not off southern California), forage and predatory fish abundance remained low, and low reproductive success of seabirds (monitored at the Farallon Islands). Although the SST 
was warmer in 2003 than in 2007, there was no difference in diet of the fulmars in these years leading me to suggest that foraging area of the birds were similar for both years (Fig. 6).

Although oceanographic features differed between the sampled years, the species of cephalopods eaten and the modified Costello plots indicated that the range prey species available to fulmars was similar. Based on these results, I propose that fulmars were foraging opportunistically on the most widely available cephalopods. Fulmars ate mostly on adult, mesopelagic Gonatid cephalopods of varying lengths and masses. Of the three dominant species, G. californiensis was the largest, G. onyx was somewhat muscular, and G. pyros was small and muscular (Nesis 1987). Gonatus californiensis is thought to be confined to the CCS region whereas Gonatus onyx and G. pyros are smaller, more common and broadly distributed species (Fig. 6).

The Fulmar diet described here is similar in species composition as described previously, although in greater detail (Table 8). Previously, researchers were lacking identification to species, distribution information, and sufficient sample sizes when describing Northern Fulmar diet. 


\section{Table 8}

Previously identified cephalopod beaks: family, species, number, and location from

\section{Northern Fulmar stomachs in earlier decades}

\begin{tabular}{|c|c|c|c|c|c|}
\hline Family & Genus/species & Sanger 1983 & Hills \& Fiscus 1988 & Baltz \& Morejohn 1977 & Gould et al. 1997 \\
\hline & & $n=46$ & $n=28$ & $\mathbf{n}=3$ & $n=29$ \\
\hline & & Gulf of Alaska & Washington Coast & Monterey Bay & West Pacific (near Japan \\
\hline Loliginidae & Doryteuthis opalescens & - & - & 8 & - \\
\hline Enoploteuthidae & Abraliopsis felis & - & 1 & _ & _ \\
\hline \multirow[t]{2}{*}{ Octopoteuthidae } & Octopoteuthis deletron & - & 3 & $\overline{5}$ & - \\
\hline & Octopoteuthis sp. & - & _ & _ & $\overline{2}$ \\
\hline Onychoteuthidae & Onychoteuthis borealijaponicu & - & 1 & $\overline{4}$ & _ \\
\hline \multirow[t]{4}{*}{ Gonatidae } & Gonatopsis borealis & - & 4 & - & 1 \\
\hline & Gonatus pyros & - & 19 & - & _ \\
\hline & Gonatus spp. & 12 & 5 & - & - \\
\hline & unid. Gonatidae & _- & 1 & 6 & - \\
\hline \multirow[t]{3}{*}{ Histioteuthidae } & Histioteuthis heteropsis & - & 2 & _ & - \\
\hline & Stigmatoteuthis dofleini & - & - & - & $\overline{\#}$ \\
\hline & unid. Histioteuthidae & - & $\overline{1}$ & - & _ \\
\hline Ommastrephidae & Ommastrephes bartrami & - & _- & - & $\overline{1}$ \\
\hline Chiroteuthidae & Chiroteuthis calyx & _ & 6 & _ & _ \\
\hline Mastigoteuthidae & Mastigoteuthis sp. & - & _ & - & $\overline{1}$ \\
\hline \multirow[t]{4}{*}{ Cranchiidae } & Taonius borealis & - & $\overline{36}$ & - & _ \\
\hline & Galiteuthis phyllura & - & _- & - & 6 \\
\hline & Leachia dislocata & - & - & - & $\#$ \\
\hline & unid. Cranchiidae & - & 1 & - & _ \\
\hline Bolitaenidae & Japetella heathi & - & 2 & - & - \\
\hline Octopodidae & Octopus sp. & - & 1 & $\overline{1}$ & - \\
\hline Alloposidae & Haliphron atlanticus & - & - & - & $\#$ \\
\hline \multicolumn{6}{|l|}{ Unidentified } \\
\hline \multirow{2}{*}{\multicolumn{2}{|c|}{$\begin{array}{l}\text { unid. Teuthoidea (juveniles) } \\
\text { unid. cephalopod beaks }\end{array}$}} & _ & _ & _ & 1 \\
\hline & & & & & 5 \\
\hline
\end{tabular}


All three dominant species of cephalopods are primarily mesopelagic, but also found in the bathypelagic zones, which raises the question of how fulmars would have access to deeper water cephalopods. Many cephalopods exhibit vertical diel migrations when in the juvenile stage, which would be one explanation for how Fulmars would have access to deeper water squids especially if they also are nocturnal foragers (Hatch et al. 2010). Another explanation for the abundance of deeper water cephalopods at the surface are die-offs of post-spawning adults. Recently, researchers operating in small vessels used the presence of foraging Procellariiforms to find dead cephalopods floating on the surface. Many of these cephalopods may have floated to the surface after deepwater spawning die-offs. Because most cephalopods eaten by fulmars were mesopelagic species normally found at depth, possibly they were consumed after floating to the surface after deepwater spawning die-offs (personal comm. William Walker 2009).

I found that one body condition index, pectoral muscle, was related to number and average beak size (LRL) per stomach, but the other condition variable, fat score was not. My results and other researchers indicate that assessing muscle complex before sampling will give an estimate of a bird's health (Hobson et al. 1993, van Franeker \& Meijboom 2002, Nevins et al. 2005). Furthermore, I found that birds with better pectoral muscle health contained remnants of more prey items suggesting they had been foraging regularly. It is thought that muscle atrophy occurs after fat reserves have been depleted in a fasting or starving bird (van Franeker \& Meijboom 2002, Nevins et al. 2005). In this study, the majority of fulmars were in poor health based on the lack of subcutaneous fat 
and reduced pectoral muscle mass (driving a significant difference in prey number between years). Ideally, equal representation of healthy vs. poor body conditions would be compared, and is suggested for future studies (Table 1).

Similarly, when examining plastic ingestion and body condition, the pectoral muscle index was an indicator of mass of total marine debris. Birds with greater pectoral muscle indices, the healthy fulmars, contained lesser masses of total debris but not fewer pieces of plastic. These results indicate that healthier fulmars do not ingest less plastic/debris, but plastics/debris that are lesser in mass (Table 5). The total marine debris category includes non-edible items that are not necessarily plastic, but that are not naturally ingested items such as: paper fragments, hardened oil pieces, coal, rubbery pieces, etc. (van Franeker \& Meijboom 2002). In Europe, hard plastics are being phased out and lighter, biodegradable items that have a starch component to them are being used (van Franeker personal comm. 2008). If biodegradable plastics break down more readily in fulmar stomachs, they will complicate the quantification of number and incidence of ingested plastics because they are more brittle. This would result in a greater number of plastic pieces, that are lesser in mass. For this reason, it is suggested that mass is a better measure of plastic ingestion in seabirds in the long term and the most representative of ecological impacts on organisms (van Franeker \& Meijboom 2002).

This study indicated an overall increase in incidence, number, and mass of plastics between 2003 and 2007. Similar to a study of Fulmars in the North Sea, I found an increase in the plastic categories in all but the industrial plastic category (van Franeker 
\& Meijboom 2002). Overall, there has been an increase in the amount of user plastic found in seabirds (Vlietstra \& Parga 2002, Nevins et al. 2005, van Franeker et al. 2005, Ryan 2008), whereas industrial plastic was more abundant in seabirds sampled in earlier decades (Day et al. 1985, Ryan 1987, Harper \& Fowler 1987). Similar plastic loads were found in Short-tailed Shearwaters (Puffinus tenuirostris) from the North Pacific sampled between the 1970s and 1990s (Vlietstra \& Parga 2002, Ryan 2008). The proportion of industrial pellets, however, had decreased from 55-73\% to 33\% (Vlietstra \& Parga 2002, Ryan 2008). In addition, from 1982 to 2000, fulmars in the North Sea had a significant decrease in ingested industrial plastic, but a significant increase in user plastic (van Franeker et al. 2005). The greater incidences of user plastic in seabirds may reflect an increase in its availability at sea, or conversely, it may reflect a decrease in industrial plastic availability (van Franeker et al. 2005, Ryan 2008). The introduction of programs preventing the loss of industrial pellets in the early 1990s may have reduced the volume of industrial plastic in the ocean (Operation Clean Sweep as cited in Ryan 2008; National Marine Debris Monitoring Program www.oceanconservancy.org), although more data is needed to test this hypothesis.

I found that the majority of birds were immature fulmars in poor body condition, a factor which could influence plastic ingestion. In addition to variables examined in this study, time, seasonal variation, origin, and cause of death, among other factors could influence the amount and type of plastic ingested (van Franeker \& Meijboom. 2002). Often, it is hypothesized that starving birds ingest more plastic. I found that healthy 
fulmars in 2007 contained less debris by mass, but not less debris by number. The North Sea fulmar study indicated that plastic loads in stomachs were not related to gradual starving of the bird (van Franeker \& Meijboom 2002). Only three birds in the best body condition had lesser plastics (not of statistical significance; van Franeker \& Meijboom 2002).

The effect of season on plastic loads in fulmars is less clear. Mallory (2006) found a difference in plastic incidence between breeding and non-breeding fulmars from Canadian colonies. Mallory (2006) did find that there was more plastic in fulmars collected earlier in the breeding season, indicating that the plastic was acquired during winter migration. Similarly, the North Sea breeding and non-breeding adults had greater plastic loads until July, then a decrease in plastic loads occurred, followed by an increase in plastic loads again in the months following (van Franeker personal comm. 2008). This suggests Fulmars are ingesting plastics in wintering areas, breaking it down, and excreting or regurgitating micro plastics to chicks within the breeding season (van Franeker et al. FulmarEcoQO Onlinel Supplement 2011).

A variable that is clearly related too plastic ingestion is age. The North Sea study indicated immatures had greater levels of plastic upon initial inspection (van Franeker \& Meijboom 2002), but after additional years in the study (2004-2009), they reported, that the age difference was consistent to a level that all different age groups could be combined in a single monitoring unit (van Franeker et al. 2011). They reported that the geometric mean mass of plastics indicated the same short term annual fluctuations and 
long-term patterns for both adults and non-adults, in spite of the substantial difference between these groups (van Franeker \& Meijoboom 2002, van Franeker et al. 2011). While this indicates that overall patterns in plastic ingestion can be applied to all age groups, this study will reference only immature, wintering Fulmars.

The Canonical correlation results indicated that fulmars carrying heavier loads of user plastic ate smaller cephalopods, but these findings were not statistically significant. These findings may be of biological relevance if trends in plastic ingestion continue. Plastic ingestion is not only increasing in fulmars in the North Sea, it also is increasing in fulmars caught in Alaska's long-line fisheries. Ingested plastic incidence in fulmars was $62 \%$ in 2005 , but increased to $72 \%$ by $2007-08$ (Nevins et al. in prep).

As ingested plastic levels increase, one would expect a critical level where dietary changes take place. Although, a critical level would be difficult to identify because it would be species-specific, based on different stomach morphologies, metabolic rates, diets, and retention times. Currently, the retention time of ingested plastics is poorly understood. The interference of ingested plastics on digestion assimilation efficiency was examined in white-chinned petrels (Procellaria aequinoctialis) in the 1980s (Ryan 1989). He found no significant difference between petrels fed polyethylene pellets and control birds, but Ryan (1989) suggested testing of other types of plastics should occur. Also, he predicted a half-life of at least one year for pellets in the stomachs of Petrels (Ryan 1989). Similarly, Day et al. (1985) suggested that retention time was approximately 6 months or more for plastic (via wear in the gizzard and passage through the gut). 
However, van Franeker et al. (2011) suggested that these papers probably overestimated the residence time of plastics in stomachs. They suggested that disappearance rates of ingested plastics was size dependent, and could be conservatively estimated at greater than $75 \%$ per month, (assuming mostly hard plastics) and lesser time for softer plastics (foamed and sheet-like materials; van Franeker et al. 2011). As user plastics increase and pellets decrease (or remain steady) in the marine environment, it becomes imperative to examine the retention times of user plastics. However, experiments that actively feed seabirds plastics are not a widely supported idea for ethical and logistical purposes. Other research that examined retention times focused solely on the time scale or seasons that ingestion was occurring (van Franeker \& Bell 1988, Mallory 2008). To understand if there is a critical level and how to define it in seabirds, the first step may be to examine retention times of prey items and hard parts on a species-specific level.

One of the biases with using prey hard parts as a proxy for seabird diet is the difference in passage rates and retention of hard parts, which is often unknown. From marine mammal diet studies, we know that cephalopod beaks are retained in predator stomachs longer than other hard parts, such as fish otoliths (Harvey 1989, Santos et al. 2001). For this reason, the importance of cephalopods in fulmar diet may be over estimated. Although I studied only cephalopod beaks and plastic (the few otoliths recovered were degraded and deteriorating) fulmars forage on a variety of other softbodied prey (e.g. amphipods, copepods; Hatch \& Nettleship 1998 ). Evidence of fish was found in this study, in addition to small copepods (which may or may not have been 
incidental intake). The fulmars sampled in 2003 were spotted by an at-sea survey team eating jellyfish gonads and picking ecto-parasites off of sunfish (Mola mola; Nevins \& Harvey 2005), although dietary evidence of these prey were not present in my samples due to efficient digestion and less retention of soft-bodied prey. A study on multiple seabird species indicated that species that are generalists and eat a variety of food types (including low quality items) usually had slow and efficient digestion and stomachs with greater mass, whereas seabirds that were specialists ate readily digestible and energy dense food types had faster and less efficient digestion (Hilton et al. 2000). In Cape Petrels (Daption capense), squid beaks decreased in number by $90 \%$ between December and January. Antarctic Petrels (Thalassoica antarctica) and Southern Fulmars (Fulmarus glacialoides) had the same pattern in cephalopod beak reduction (Van Franeker et al. FulmarEcoQO Online Supplement 2011). Being that beaks are of similar durability as hard plastics, it is assumed that retention times were similar in Northern Fulmars, and that $75 \%$ of beaks ingested at the beginning of the month had passed through the digestive system by the end of the month (van Franeker et al. FulmarEcoQO Onlinel Supplement 2011). If this is true and most plastics, cephalopod beaks, and other prey items are retained for about a month, a critical level at which plastics interfere with prey consumption may be of less importance.

How plastic ingestion affects individuals, populations of seabirds, and other marine life is of continued importance as the use of plastics around the world increases. There are other issues with plastic ingestion that are outside the scope of this study that include 
contaminants, accumulation, endocrine disrupters, and micro plastics infiltrating prey

sources. These issues are key components to understanding how prey and plastic

ingestion are correlated, and the overall negative health effects that plastic ingestion have on Northern Fulmars. 


\section{Literature cited}

Auman, H. J., Ludwig, J. P. \& T. Colborn. 1997. Plastic ingestion by Laysan Albatross chicks on Sand Island, Midway Atoll, in 1994 and 1995. In: Robinson, G. \& Gales, R. (Eds.) Albatross biology and conservation. Chipping Norton: Surrey Beatty \& Sons. pp. 239-244.

Azzarello, M. Y. \& E. S. Van Vleet. 1987. Marine birds and plastic pollution. Marine Ecology Progress Series. 37: 295-303.

Baltz, D. M. \& G. V. Morejohn. 1977. Food habits and niche overlap of seabirds wintering in Monterey Bay, California. The Auk. 94(3): 526-543.

Boyle P. R. \& S. V. Boletzky. 1996. Cephalopod populations: Definition and dynamics. Philosophical Transactions: Biological Sciences. 351(1343): 985-1002.

Bros, S. M. (2009). Personal communication.

California Cooperative Oceanic Fisheries Investigations. 2005. The state of the Calfornia current, 2003-2004: A rare “normal” year. CalCOFI Rep. 45: 1-33.

California Cooperative Oceanic Fisheries Investigations. 2009. The state of the Calfornia current, 2007-2008: La Nina conditions and their effects on the ecosytem. CalCOFI Rep. 50: 1-38.

Clarke, M. R. 1986. A handbook for the identifications of cephalopod beaks. Oxford: Clarendon Press.

Connors, P. G. \& K. G. Smith. 1982. Oceanic plastic particle pollution: suspected effect on fat deposition in red phalaropes. Marine Pollution Bulletin. 13: 18-20.

Day, R. H. 1980. The occurrence and characteristics of plastic pollution in Alaska's marine birds. Master’s Thesis, University of Alaska, Fairbanks. 111.

Day, R. H., D. H. S. Wehle \& F. C. Coleman. 1985. Ingestion of plastic pollutants by marine birds. In: Proceedings of the Workshop Fate and Impact of Marine debris, 26-29 November 1984. (R. S. Shomura \& H. O. Yoshida Eds.) Honolulu, Hawaii. U.S. Department of Commerce, NOAA Technical Memorandum NOAA-TM-NMFS-SWFC-54. 
Eriksson, C. \& H. Burton. 2003. Origins and biological accumulation of small plastic particles in fur seals from Macquarie Island. Ambio. 32(6):380-384.

Frey, M. D., Fefer, S. I \& L. Sileo. 1987. Ingestion of plastic debris by Laysan albatrosses and wedge-tailed shearwaters in the Hawaiian Islands. Marine Pollution Bulletin. 18: 339-343.

Furness, R. W. 1985. Ingestion of plastic by seabirds at Gough Island, South Atlantic Ocean. Environmental Pollution, Series A. 38:261-272.

Gould, P., Walker, W. \& P. Ostrom. 1997. Foods of Northern Fulmars associated with high-seas drift nets in the transitional region of the north Pacific. Northwestern Naturalist. 78:57-61.

Hatch, S. A. 1991. Evidence for color phase effects on the breeding and life history of Northern Fulmars. Condor. 93(2):409-417.

Hatch, S. A., Gill, V. A. \& D. M. Mulcahy. 2010. Individual and colony-specific wintering areas of Pacific northern fulmars (Fulmarus glacialis). Canadian Journal of Fisheries and Aquatic Sciences. 67:386-400.

Harvey, J. T. 1989. Assessment of errors associated with Harbor Seal (Phoca vitulina) fecal sampling. Journal of Zoology Lond. 219:101-111.

Hills, S. \& C. H. Fiscus. 1988. Cephalopod beaks for the stomachs of Northern Fulmars (Fulmarus glacialis) found dead on the Washington Coast. The Murrlet. 69(1): 15-20.

Hilton, G. M., Furness, R. W. \& D. C. Houston. 2000. A comparative study of digestion in North Atlantic seabirds. Journal of Avian Biology. 31(1): 36-46.

Hobson, K. A., Alisauskas, R. T., \& R. G. Clark. 1993. Table-nitrogen isotope enrichment in avian tissues due to fasting and nutritional stress: implications for isotopic analyses of diet. The Condor. 95(2):388-394.

Jessup, D. A., Miller, M. A., Ryan, J. P., Nevins, H. M., Kerkering H. A. et al. (2009). Mass stranding of marine birds caused by a surfactant-producing red tide. PLoS ONE. 4(2): e4550. doi.10.1371/journal.pone.0004550 
Mallory, M. L., Roberston, G. J. \& A. Moenting. 2006. Marine plastic debris in northern fulmars from Davis Strait, Nunavat, Canada. Marine Pollution Bulletin.52: 800815.

Montevecchi, W. A. \& R. A. Myers. 1996. Dietary changes of seabirds indicate shifts in pelagic food webs. 80(4): 312-322.

Nesis, K. N. 1987. Cephalopods of the world. Squids, Cuttlefishes, Octopuses and Allies. TFH Publications, New Jersey, 351 pp.

Nevins, H., Hyrenbach, D., Keiper, C., Stock, J., Hester M. \& J. Harvey. 2005. Seabirds as indicators of plastic pollution in the North Pacific. Paper for Plastic Debris Rivers to Sea Conference. 1-12.

Pettit, T. N., Grant G. S. \& G. C. Whittow. 1981. Ingestion of plastics by Laysan albatross. The Auk. 98: 839-841.

Pierce, K., Harris, R. J., Larned, L. S. \& M. A. Pokras. 2004. Obstruction and starvation associated with plastic ingestion in a Northern Gannat Morus bassanus and a Greater Shearwater Puffinus gravis. Marine Ornithology. 32:187-189.

Polovina, J. J., Howell, E., Kobayashi, D. R. \& Seki M. P. 2001. The transition zone chlorophyll front, a dynamic global feature defining migration and forage habitat for marine resources. Progress in Oceanography. 29: 469-483.

Robards, M. D., Piatt J. F. \& K. D. Wohl. 1995. Increasing frequency of plastic particles ingested by seabirds in the subarctic North Pacific. Marine Pollution Bulletin. 30: 151-157.

Robards, M.D., Gould, P.J. \& J. F. Piatt. 1997. The highest global concentrations and increased abundance of oceanic plastic debris in the North Pacific: evidence from seabirds. In: Coe, J.M., Rogers, D. B. (Eds.), Marine debris-Sources, Impacts, and Solutions. Springer-Verlag, New York, pp. 71-80.

Rodhouse, P. G \& Ch. M. Nigmatullin. 1996. The role of cephalopods in the world's oceans: Role as Consumers. Philosophical Transactions: Biological Sciences. 351(1343): 1003-1022.

Ryan, P. G. 1987. The incidence and characteristics of plastic particles ingested by seabirds. Marine Environmental Research. 23: 175-206. 
Ryan, P. G. 1988. Effects of ingested plastic on seabird feeding: evidence from chickens. Marine Pollution Bulletin. 19: 125-128.

Ryan, P. G. 1989. The effects of ingested plastic and other marine debris on seabirds. Proceedings of the Second International Conference. 19:174-176.

Ryan, P. G. 2008. Seabirds indicate changes in the composition of plastic litter in the Atlantic and south-western Indian oceans. Marine Pollution Bulletin. 56: 1406-1409.

Sanger, G. A. 1983. Diets and food web relationships in the Gulf of Alaska and adjacent marine regions. Final Report to Outer Continental Shelf Environment Assessment Program (OC-SEAP). 130 pp.

Santos, M. B., Clarke, M.R. \& G. J. Pierce. 2001. Assessing the importance of cephalopods in the diets of marine mammals and other top predators: problems and solutions. Fisheries Research. 52(1-2):121-139.

Seki, M. P., Polovina, J. J., Kobayashi, D. R., Bidigare, R. R. \& G. T. Mitchum. 2002. An oceanographic characterization of swordfish (Xiphias gladius) longline fishing grounds in the springtime subtropical North Pacific. Fisheries Oceanography. 11:251-266.

Sileo, L., Sivert, P. R., \& M. D. Samuel. 1989. Prevalence and characteristics of plastic ingested by Hawaiian seabirds. In: Proceedings of the Second International Conference on Marine Debris ed by R. S. Shomura and M. L. Godfrey. 2-7 April 1989, Honolulu, Hawaii. U.S. Dep. Commerce, NOAA, Techical Memorandum. pp. 665-81.

Sivert, P. R \& L. Sileo. 1993. The effects of ingested plastic on growth and survival of albatross chicks. In: Vermeer, K., Briggs, K. T., Morgan, K. H. \& Siegal-Causey D. (Eds.). The status, ecology, and conservation of marine birds of the North Pacific. Ottawa: Canadian Wildlife Service Special Publication. pp. 212-217.

Spear, L. B., Ainley, D. G. \& C. A. Ribic. 1995. Incidence of plastic in seabirds from the tropical Pacific, 1984-91: relation with distribution of species, sex, age, season, year, and body weight. Marine Environmental Research 40: 123-146. 
Suryan, R. M., Irons, D. B., Kaufman, M., Benson, J., Jodice, P. G. R., Roby, D. D. \& E. D. Brown. 2002. Short-term fluctuations in forage fish availability and the effect on prey selection and brood-rearing in the black-legged kittiwake Rissa tridactyla. Marine Ecology Progress Series. 236: 273-287.

Suter, W. 1997. Roach rules: shoaling fish are a constant factor in the diet of cormorants Phalacrocorax carbo in Switzerland. Ardea. 85: 9-27.

Sydeman, W. J., Hester, M. M., Thayer, J. A., Gress, F., Martin, P. \& J. Buffa. 2001. Climate change, reproductive performance and diet compostions of marine birds in the southern California Current System, 1969-1997. Progress in Oceanography. 49: 309-329.

Van Franeker, J. A. 1985. Plastic ingestion in the North Atlantic Fulmar. Marine Pollution Bulletin. 16: 367-369.

Van Franeker, J. A. \& P. J. Bell. 1988. Plastic ingestion by petrels breeding in Antarctica. Marine Pollution Bulletin. 19(12):672-674.

Van Franeker, J. A. \& A. Meijboom. 2002. Litter NSV: Marine litter monitoring by Northern Fulmars (a pilot study). Alterra-rapport 401, ISSN 1566-7197. 72p.

Van Franeker, J. A., Heubeck, M., Fairclough, K., Turner, D. M., Grantham, M., Stienen, E. W. M., Guse, N., Pedersen, J., Olsen, K. O., Andersson, P. J. \& B. Olsen. 2005. 'Save the North Sea' fulmar study 2002-2004: a regional pilot project for the Fulmer-Litter-EcoQO in the OSPAR area. Alterra-rapport 1162, Wageninge.

Van Franeker, J. A. \& The SNS Study Group. 2011. Fulmar Litter EcoQO monitoring along Dutch and North Sea coasts in relation to EU Directive 2000/59/EC on port reception facilities: results to 2009. IMARES Report Nr Co37/11. IMARES, Texel.

Walker, W. A. (2009). Personal Communication.

Young, L. C., Vanderlip C., Duffy, D. C., Vsevolod, A. \& S. A. Shaffer. 2009. Bringing home the trash: Do colony-based differences in foraging distribution lead to increased plastic ingestion in Laysan Albatrosses? PLoS ONE. 4(10): e7623 doi: 10.1371/journal.pone.0007623

Zar, J. H. 1999. Biostatistical Analysis. Fourth Edition. Prentice-Hall, Inc., NJ. 
Zonfrillo, B. 1985. Petrels eating contraceptives, polythene and plastic beads. British Birds. 78: 350-351. 